Progress in Earth and Planetary Science

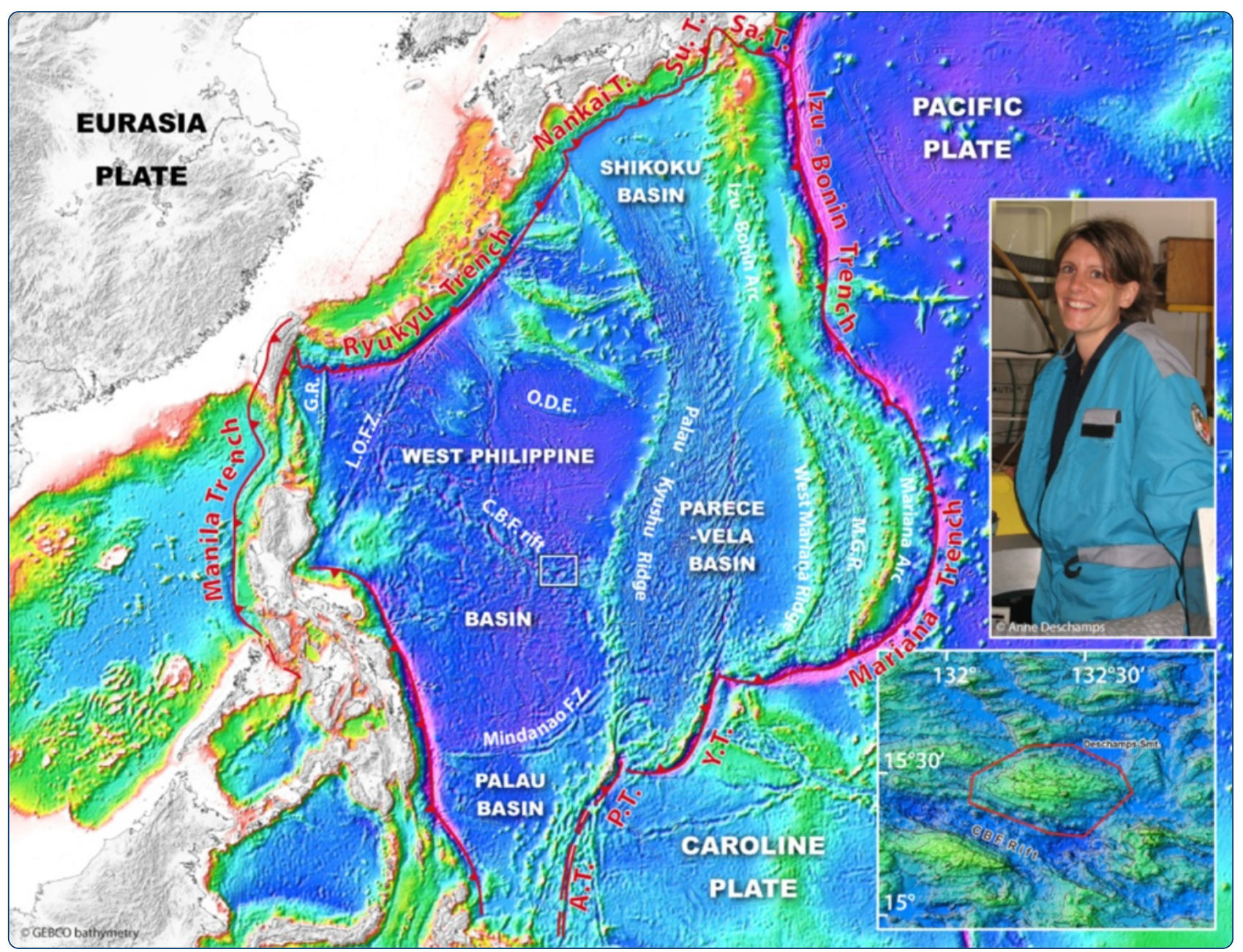

\title{
Philippine Sea Plate inception, evolution, and consumption with special emphasis on the early stages of Izu-Bonin-Mariana subduction
}

Lallemand

Springer Open 
Open Access

\title{
Philippine Sea Plate inception, evolution, and consumption with special emphasis on the early stages of Izu-Bonin-Mariana subduction
}

Serge Lallemand ${ }^{1,2}$

\begin{abstract}
We compiled the most relevant data acquired throughout the Philippine Sea Plate (PSP) from the early expeditions to the most recent. We also analyzed the various explanatory models in light of this updated dataset. The following main conclusions are discussed in this study. (1) The Izanagi slab detachment beneath the East Asia margin around 60-55 Ma likely triggered the Oki-Daito plume occurrence, Mesozoic proto-PSP splitting, shortening and then failure across the paleo-transform boundary between the proto-PSP and the Pacific Plate, Izu-Bonin-Mariana subduction initiation and ultimately PSP inception. (2) The initial splitting phase of the composite proto-PSP under the plume influence at 54-48 Ma led to the formation of the long-lived West Philippine Basin and short-lived oceanic basins, part of whose crust has been ambiguously called "fore-arc basalts" (FABs). (3) Shortening across the paleo-transform boundary evolved into thrusting within the Pacific Plate at 52-50 Ma, allowing it to subduct beneath the newly formed PSP, which was composed of an alternance of thick Mesozoic terranes and thin oceanic lithosphere. (4) The first magmas rising from the shallow mantle corner, after being hydrated by the subducting Pacific crust beneath the young oceanic crust near the upper plate spreading centers at 49-48 Ma were boninites. Both the so-called FABs and the boninites formed at a significant distance from the incipient trench, not in a fore-arc position as previously claimed. The magmas erupted for 15 m.y. in some places, probably near the intersections between back-arc spreading centers and the arc. (5) As the Pacific crust reached greater depths and the oceanic basins cooled and thickened at $44-45 \mathrm{Ma}$, the composition of the lavas evolved into high-Mg andesites and then arc tholeiites and calc-alkaline andesites. (6) Tectonic erosion processes removed about 150-200 km of frontal margin during the Neogene, consuming most or all of the Pacific ophiolite initially accreted to the PSP. The result was exposure of the FABs, boninites, and early volcanics that are near the trench today. (7) Serpentinite mud volcanoes observed in the Mariana fore-arc may have formed above the remnants of the paleo-transform boundary between the proto-PSP and the Pacific Plate.
\end{abstract}

Keywords: Philippine Sea Plate, Izu-Bonin-Mariana, Subduction initiation, Boninite, Fore-arc basalt, Serpentinite mud volcano, Back-arc basin, Transform fault, Arc terrane, Plume-ridge interaction 


\section{Introduction}

The visible part of the Philippine Sea Plate (PSP) has a diamond shape with a maximum north-south length of $\sim 3400 \mathrm{~km}$ and a maximum east-west width of $\sim 2600 \mathrm{~km}$. Its extent below southwest Japan, the Ryukyu Arc, and the Philippine Arc (see Fig. 1) is outlined by the Benioff zones and tomography anomalies (Kao and Chen 1991; Bijwaard et al. 1998; Wang et al. 2008). Removal of the PSP edges through tectonic erosion has also been documented, especially along the Izu-Bonin-Mariana (IBM) Trench (Hussong and Uyeda 1981; Bloomer 1983; Fryer et al. 1992; Lallemand 1995). Considering that the eastern Shikoku, Parece Vela and Mariana basins, which opened as back-arc basins (Karig 1971a; Uyeda and Ben Avraham 1972) during the Neogene, it is clear that the shape and area of the PSP has changed over time. The PSP subducts under southwest Japan and the Ryukyu Arc along its northwestern side, and under the Philippine Arc along its southwestern side. Conversely, it overrides the Pacific
Plate along its eastern edge (fringed by the IBM Arc) and its central-western edge (fringed by the Luzon Arc). To summarize, most of its boundaries consist of subduction zones except a small divergent segment in the south, called the Ayu Trough (Fujiwara et al. 1995).

Many authors have contributed to our understanding of the tectono-magmatic evolution of the PSP (e.g., Uyeda and Ben Avraham 1972; Hilde and Lee 1984; Seno and Maruyama 1984; Hickey-Vargas 1991; Stern and Bloomer 1992; Hall et al. 1995a; Okino et al., 1999; Deschamps and Lallemand 2002). From among this group, I would like to dedicate this review to Anne Deschamps who recently departed.

The main objectives of this review paper are as follows:

- to scan the nature and age of the various parts of the PSP including the subducted and eroded parts that represent about one third of its total area.

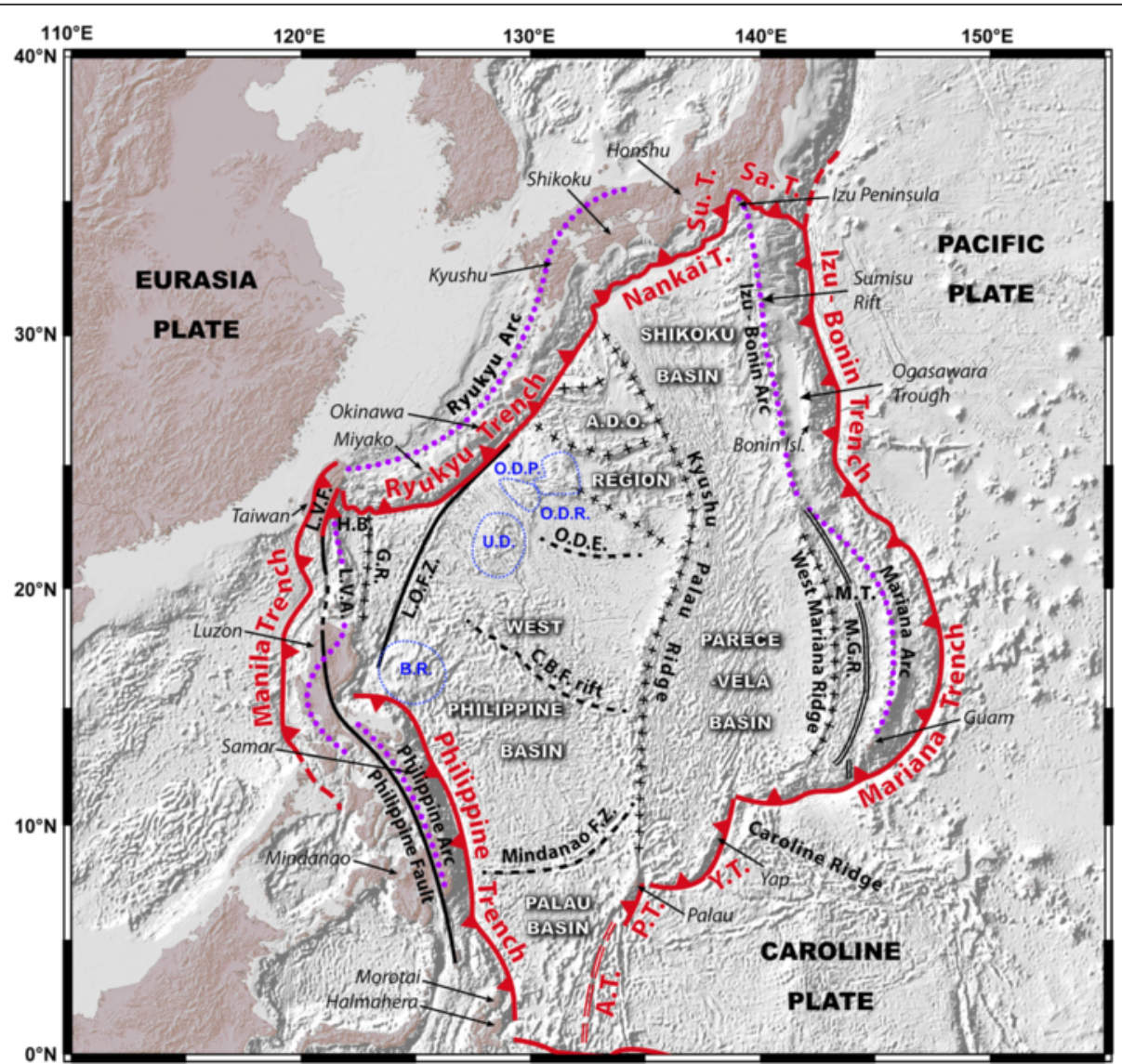

Fig. 1 Philippine Sea Plate boundaries and toponymy. Plate boundaries (in red) are reported on a bathymetric map based on GEBCO data. Main faults are represented by thick black lines and active spreading centers by double lines. Red triangles are located on the overriding plates along the subduction boundaries. Blue dotted lines outline the OIB plateaus. From north to south: Su.T. Suruga Trough, Sa.T. Sagami Trough, Nankai T. Nankai Trough, A.D.O. Region Amami-Daito-Oki-Daito Region, Bonin Isl. Bonin Islands, O.D.P. Oki-Daito Plateau, O.D.R. Oki-Daito Ridge, U.D. Urdaneta Plateau, O.D.E. Oki-Daito Escarpment, L.V.F. Longitudinal Valley Fault, H.B. Huatung Basin, G.R. Gagua Ridge, L.V.A. Luzon Volcanic Arc, L.O.F.Z. Luzon-Okinawa Fracture Zone, B.R. Benham Rise, C.B.F. rift Central Basin Fault rift, M.T. Mariana Trough, M.G.R. Malaguana-Gadao Ridge, Mindanao F.Z. Mindanao Fracture Zone, Y.T. Yap Trench, P.T. Palau Trench, and A.T. Ayu Trough 
- to portray the major tectonic events that have shaped the PSP such as its inception, subduction initiation, intraplate deformation including shortening, rifting and spreading, or tectonic erosion and subduction along some of its boundaries.

- ultimately, to give rise to new insights into the PSP tectonic evolution and serve as a guide for new investigations.

\section{Review \\ Overview of the non-subducted part of the present-day PSP}

The boundaries of the PSP have changed tremendously through time. Indeed, most of the so-called "Philippine mobile belt" still belonged to the PSP during the Miocene (e.g., Moore and Silver 1982; Lewis and Hayes 1983; Hall 1987; Rangin et al. 1990; Lallemand et al. 1998). In the past, the transpressive plate boundary was located either west of or within the archipelago. The reader can refer to Pubellier et al. (2004) among others for accounts of the huge continental and oceanic sliver motions of this area during the Neogene. The southeastern boundary, i.e., Mariana and Yap Trenches in particular, considerably lengthened through time to accommodate the spreading of the West Philippine Basin, PareceVela Basin, and Mariana Trough (Fig. 1; Deschamps and Lallemand 2002; Kobayashi 2004; Okino et al. 2009; Ribeiro et al. 2013). In this section, we will focus on the visible part of the present-day PSP, aiming to trace the various pieces of the puzzle that result from a multi-stage tectonic evolution.

\section{Present-day boundaries of the PSP}

The PSP was the fastest-moving plate during Cenozoic times (Zahirovic et al. 2015). Today, the absolute motion of its southern part $(\sim 10 \mathrm{~cm} /$ year $)$ in classical reference frames (DeMets et al. 2010; Seton et al. 2012 or Kreemer et al. 2014) is comparable to that of the Pacific Plate, which is presently the fastest plate in the world. The high speed of these two plates is primarily due to the slab pull force exerted along their northwestern boundaries (i.e., Forsyth and Uyeda 1975; Spence 1987; Pacanovsky et al. 1999; Faccenna et al. 2007). The PSP subducts toward the northwest along $\sim 2500 \mathrm{~km}$ of the Ryukyu Trench and Nankai Trough and $1500 \mathrm{~km}$ of the Philippine Trench (Fig. 1). This dominant force controls the northwest motion of the plate. The plate is surrounded by subduction zones. It is the down-going plate along most of its western edges, and the overriding plate along its eastern edge (marked by the Izu-Bonin-Mariana, Yap and Palau trenches) and the central part of its western edge (marked by the Manila Trench). There, between Luzon and Taiwan, the plate boundary is not a single distinct unit because the eastward-dipping Manila Trench overlaps the westward- dipping Philippine Trench at the latitude of Luzon island and the northward-dipping Ryukyu Trench at the latitude of Taiwan. In the vicinity of both islands, the relative convergence between the Eurasian Plate and the PSP is accommodated along several faults, which include the Longitudinal Valley Fault and deformation front in Taiwan (Angelier 1986) and the Philippine Fault and Manila Trench in Luzon (Pubellier et al. 2004). In the south, the short Palau Trench extends over a distance of $\sim 500 \mathrm{~km}$ into a slow-spreading ridge, called the Ayu Trough, which is supposed to have been active since $25 \mathrm{Ma}$ (Weissel and Anderson 1978; Fujiwara et al. 1995). The southernmost E-W-trending boundary corresponds to an area of diffuse strike-slip deformation, which includes the Sorong Fault (Hall 1987). There are two major collisions between active volcanic arcs carried by the PSP and the adjacent margins. One is in the west with the Luzon volcanic arc. It has resulted in the Taiwan orogeny since the Pliocene (e.g., Angelier 1986; Lallemand et al. 2001; Malavieille et al. 2002). The other is in the north with the IBM arc. It has resulted in the development of the Izu Collision Zone since the Upper Miocene (e.g., Taira et al. 1989; Aoike 2001; Arai et al. 2009). Lallemand (2014) described the deformation modes of the subducting PSP associated with these two arc-continent collisions.

The PSP itself appears as a mosaic of oceanic basins, aseismic ridges, plateaus, fracture zones, volcanic arcs and fore-arcs, fossil, and active spreading centers. Despite some controversy on the age of the small westernmost Huatung Basin (see Fig. 1), oceanic basins are younger from west to east.

\section{Oceanic basins of the PSP}

The West Philippine Basin (WPB) is the largest of the PSP oceanic basins at $\sim 1500 \mathrm{~km}$ long and $1100 \mathrm{~km}$ wide. It occupies more than one third of the plate's surface. The main scar, which is east of Luzon and trends WNW-ESE, was initially called the Central Basin Fault (CBF). Mrozowski et al. (1982) and then Hilde and Lee (1984) demonstrated that symmetric spreading occurred on both sides of that feature, which was thus identified as a fossil spreading center and renamed the CBF rift. Its unusual depth, which reaches a maximum of $7900 \mathrm{~m}$, has been explained by post-spreading amagmatic extension (Fujioka et al. 1999; Deschamps et al. 1999, 2002; Okino and Fujioka 2003). Several ridge jumps, plateau emplacements and overlapping spreading centers were interpreted by Deschamps et al. $(2002,2008)$ as the expression of plume-ridge interaction in the image of the spreading pattern in the North Fiji Basin (Lagabrielle et al. 1997; Faccenna et al. 2010). Taylor and Goodliffe (2004), mainly based on a single line acquired south of the CBF rift, suggested that the opening direction of the basin rotated $100^{\circ}$ clockwise in the period from $48-49$ 
to $33 \mathrm{Ma}$. Another striking difference from the initial model proposed by Hilde and Lee (1984) concerns the northernmost and southernmost parts of the WPB. Deschamps and Lallemand (2002) showed that magnetic lineations trend N-S north of the Oki-Daito escarpment (ODE, Figs. 1 and 2), i.e., perpendicular to the main trend on both sides of the CBF rift. They postulate that this piece of oceanic crust was the oldest in the WPB based on a dated basalt collected at site 294/5. According to their interpretation, rifting may have started as soon as $55 \mathrm{Ma}$ ago behind the proto-Philippine Arc.

Recently, Sasaki et al. (2014) provided new insights on the southernmost part of the WPB including the Palau Basin, south of the Mindanao Fracture Zone (FZ, see Fig. 1). Based on three short magnetic profiles across the Palau Basin and a dolerite sampled along the Mindanao FZ dated at $40 \mathrm{Ma}$ (Ishizuka et al. 2015), they concluded that the Palau Basin exhibits N-S magnetic lineations, as it does north of the ODE. Their magnetic model, even poorly constrained, provides an age of 35-40 Ma, which is quite young compared to its counterpart in the north. Whatever the age of this basin, it is now clear that it is made of normal oceanic crust and spreading occurred E-W (in its present position) south of the Mindanao FZ. The first estimate of the spreading period based on magnetic lineations by Hilde and Lee (1984) of between 60 and $35 \mathrm{Ma}$ was revised by Deschamps and Lallemand (2002) to from 54 to 33/30 Ma with a short, late extension episode between 30 and $26 \mathrm{Ma}$. Other authors (Taylor and Goodliffe 2004; Sasaki et al. 2014) refute the oldest ages proposed by Hilde and Lee (1984) in the southern part of the WPB because it has been proved that the seafloor fabric changes drastically south of the Mindanao FZ. Unlike most previous authors, Sasaki et al. (2014) consider a constant spreading rate for the opening of the WPB and a progressive cessation of spreading from $37.5 \mathrm{Ma}$ in the southeast to $35.5 \mathrm{Ma}$ in the northeastern part of the CBF rift.

Hilde and Lee (1984) also supposed that the WPB extended westward in the Huatung Basin across the northsouth trending Gagua Ridge, whereas Deschamps et al. (2000) argued that dredged gabbros, dated as Early Cretaceous in the Huatung Basin, invalidated this hypothesis. The age of this small basin is highly controversial. Estimates vary from 131 to $119 \mathrm{Ma}$ (Deschamps et al. 2000) to 52-43 Ma for the northern part and Early Cretaceous for the southern part (Sibuet et al. 2002), to 44-33 Ma (Hilde and Lee, 1984), 42-33 Ma (Doo et al. 2015), or even $\sim 30-15 \mathrm{Ma}$ (Kuo et al. 2009). Further details and an interesting discussion about this controversy are available in Eakin et al. (2015).

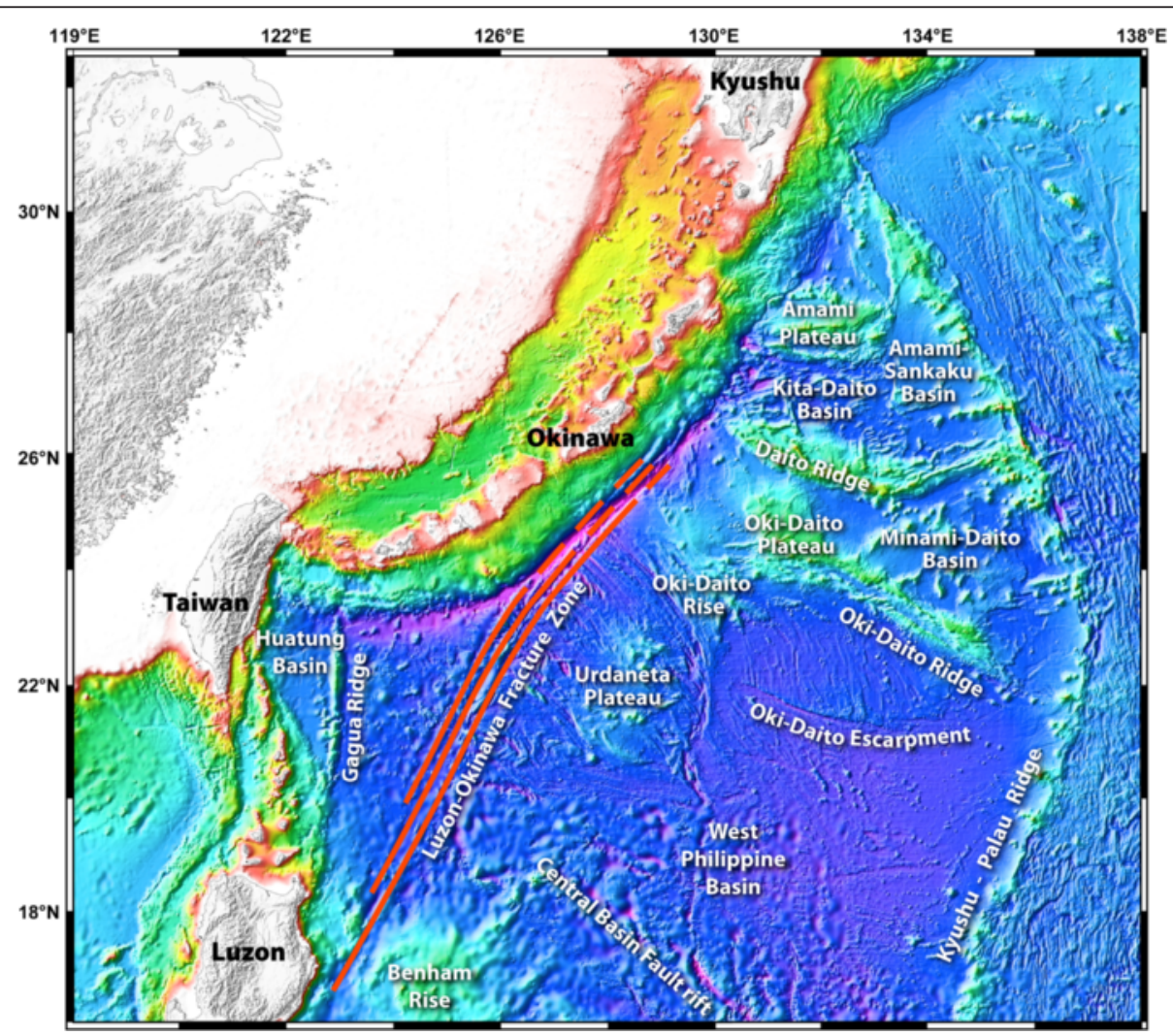

Fig. 2 Close-up view of the bathymetry of the northern half of the WPB. Details of the Amami-Daito-Oki-Daito region, Gagua Ridge and LuzonOkinawa Fracture Zone are outlined 
East of the WPB lies a north-south elongated ( $2500 \mathrm{~km}$ long by $\sim 200-600 \mathrm{~km}$ wide) pair of oceanic basins called Shikoku and Parece Vela. Both basins rifted right after the cessation of spreading in the WPB, i.e., \%30 Ma ago, then spreading occurred between 29-26 and $15 \mathrm{Ma}$ (Chamot-Rooke et al. 1987; Okino et al. 1994, 1998). Sdrolias et al. (2004) further detailed the kinematics of this "twin-back-arc opening," characterizing it as the consequence of Pacific slab rollback and PSP clockwise rotation. The back-arc region ruptured simultaneously in the north on the Shikoku rift and in the south on the Parece Vela rift about $2500 \mathrm{~km}$ apart. Spreading centers propagated toward each other and merged at $\sim 23 \mathrm{Ma}$, forming an R-R-R triple junction that accommodated the difference in the spreading orientations of the two basins. The dramatic change in spreading orientation and rate after $20 \mathrm{Ma}$ is interpreted by Sdrolias et al. (2004) as the expression of PSP rotation.

The youngest oceanic basin, the Mariana Trough, which is $\sim 1000 \mathrm{~km}$ long and $\sim 200 \mathrm{~km}$ wide, has opened behind the Mariana Arc since 6-8 Ma (Hussong and Uyeda 1981; Fryer 1995; Stern et al. 2003; Kato et al. 2003). Many authors have studied the morphological, geophysical, and petrological characteristics of this basin (Karig 1971b; Baker et al. 1996; Yamazaki and Murakami 1998; Stüben et al. 1998; Martinez et al. 1995, 2000; Deschamps and Fujiwara 2003; Deschamps et al. 2005). The asymmetric (full) spreading rate varies from $20 \mathrm{~mm} /$ year in the north to $40 \mathrm{~mm} /$ year in the south (Asada et al. 2007). This is partly responsible for the curvature of the arc and its stretching, especially south of Guam where a rift crossing the arc and the fore-arc accommodates the spreading (Ribeiro et al. 2013; Stern et al. 2013).

The Izu-Bonin Arc, north of the Mariana Arc, has also been affected by trench-perpendicular extension since $2 \mathrm{Ma}$ but the neo-formed intra-arc basin, $120 \mathrm{~km}$ long and $\sim 40 \mathrm{~km}$ wide, called the Sumisu Rift (Fig. 1), is still in the rifting stage (Taylor et al. 1990, 1991).

\section{Aseismic ridges and plateaus of the PSP}

The PSP oceanic basins are separated by aseismic ridges and plateaus, except along the eastern edge where active volcanic arcs bound the Mariana Trough and Sumisu Rift (see Fig. 1). The longest $(2600 \mathrm{~km})$ aseismic ridge, called the Kyushu-Palau Ridge (KPR), trends northsouth in the middle of the plate. It is a remnant arc (Karig 1972) separated from the IBM active volcanic arc $25 \mathrm{Ma}$ ago (Ishizuka et al. 2011a during the opening of the Shikoku and Parece Vela back-arc basins. It consists of aligned volcanoes over a width of $\sim 50-150 \mathrm{~km}$, presenting a marked change in the orientation from NNWSSE to NNE-SSW around $\sim 23^{\circ}$ N. Similarly, the aseismic West Mariana Ridge is a remnant arc that separated from the Mariana active volcanic arc $\sim 7$ Ma ago (Karig and Glassley 1970; Gardner 2010). Both the KPR paleoarc on one side and the Izu-Bonin arc and the West Mariana Ridge on the other side are conjugate margins of the Shikoku and Parece Vela basins.

West of the KPR, there are two regions with aseismic ridges, a large complex triangular-shaped region, called the Daito Ridges region or Amami-Daito-Oki-Daito (ADO) region, that lies north of the WPB, and a sharp linear ridge trending north-south, west of the WPB close to Taiwan, called the Gagua Ridge (Fig. 2).

The ADO region comprises three ridges from north to south: the Amami Plateau, the Daito Ridge, and the OkiDaito Ridge and Plateau (Fig. 2). Tokuyama (1985, 2007), based on petrology, concluded that the Amami Plateau, composed of three 200-km-long E-W-trending ridges, was an active island arc before the Eocene (Nishizawa et al. 2014). It is presently subducting beneath the Ryukyu Arc. South of the Amami Plateau, the Daito Ridge extends E-W for more than $500 \mathrm{~km}$. It also subducts on its western side and connects with the KPR on its eastern side. Basalts collected there also indicate an island arc setting (Tokuyama et al. 1986). Further south, the Oki-Daito Ridge s.l., which is $700 \mathrm{~km}$ long, is composed, from west to east, of the Oki-Daito Rise, the Oki-Daito Plateau, and the Oki-Daito Ridge s.s. Volcanic edifices on the Oki-Daito Ridge, as well as in the Minami-Daito Basin north of it, have similar ocean island basalt (OIB) signatures and an estimated age of 44-48 Ma (Ishizuka et al. 2013). Most of the Daito ridges probably originated from island arcs, based on their similar velocity structures (Nishizawa et al. 2014) and their petrology (Hickey-Vargas 2005; Ishizuka et al. 2013). The Oki-Daito Rise, southwest of the main ridge, is an exception in terms of velocity structure, as it has a thinner crustal section. Nishizawa et al. (2014) concluded that it is quite clear from velocity structure and magnetism that the Kita-Daito Basin resulted from the splitting of the Amami Plateau and Daito Ridge, but there are no distinctive features indicative of subduction along the southern edge of the Daito Ridge as earlier suggested by Tokuyama et al. (1986).

In the northwestern part of the WPB, we distinguish two broad highs at equal distances from the CBF rift (Fig. 2), the Benham Rise east of Luzon and the Urdaneta Plateau south of Okinawa. Ocean Island Basalt (OIB)-like lavas dated at $\sim 36 \mathrm{Ma}$ were sampled on the Benham Rise (Hickey-Vargas 1998), and Deschamps et al. (2008) described overlapping spreading centers near the Urdaneta Plateau. All these observations strongly support the influence of a mantle plume called the "OkiDaito mantle plume" contemporaneous with the first stages of the WPB rifting and spreading (Deschamps and Lallemand 2002; Ishizuka et al. 2013). The three 
small basins sandwiched between the Daito ridges, i.e., from south to north the Minami-Daito Basin, the KitaDaito Basin and the Amami-Sankaku Basin, are poorly known. Their crustal thickness is typical of oceanic crust (Nishizawa et al. 2014), and the few available samples, obtained from drilling in the Minami-Daito Basin, give ages for OIB sills of $\sim 51$ and $\sim 43 \mathrm{Ma}$ (Hickey-Vargas, 1998). E-W-trending magnetic lineations in the KitaDaito Basin are indicative of N-S spreading (Nishizawa et al. 2014). The Amami-Sankaku Basin was drilled during the last International Ocean Discovery Program (IODP) expedition 351. Preliminary results suggest a 50-55 m.y. old basaltic basement geochemically similar with "fore-arc basalts" from the IBM arc (see discussion in section 1.5, Expedition 351 Scientists 2015; Ishizuka et al. 2015). Finally, the small oceanic basins in the ADO region are roughly contemporaneous with the first stages of WPB spreading and could be considered to be the result of short-lived multiple spreading centers originating from the same regional magmatic event (Deschamps and Lallemand 2003).

East of Taiwan, the $300 \mathrm{~km}$-long, $4 \mathrm{~km}$-high Gagua Ridge trends north-south along $123^{\circ} \mathrm{E}$. This high separates the small Huatung Basin to the west from the main WPB to the east. Magnetic lineations of the Huatung Basin intersect the ridge at an angle of $90^{\circ}$, which strongly suggests that the Gagua Ridge was a former fracture zone (Mrozowski et al. 1982; Hilde and Lee 1984; Deschamps et al. 1998). On the west side of the ridge, magnetic lineations of the WPB are highly oblique, so the Gagua Ridge is a non-transform discontinuity (NTD). Velocity and gravity models across the ridge suggest an episode of westward underthrusting of the WPB oceanic crust beneath the Huatung Basin (Deschamps et al. 1998; Eakin et al. 2015). The Gagua Ridge thus represents failed subduction along a former fracture zone or transform boundary between two oceanic basins. That episode of short-lived subduction occurred in the Oligocene according to Deschamps and Lallemand (2002), whereas Eakin et al. (2015) favor a younger Miocene age.

Non-transform discontinuities and fracture zones of the PSP Among the NTDs and fracture zones observed in the PSP, some are prominent like the Luzon-Okinawa Fracture Zone (LOFZ), or the numerous curved fracture zones that offset the short segments of the Parece Vela spreading center. Others are suspected based on their orthogonality with the seafloor fabric such as the ODE, the Mindanao FZ, the Gagua Ridge or even the OkiDaito Ridge. The LOFZ consists of a bundle of two to four parallel NE-SW-trending strike-slip faults offsetting the westernmost piece of the WPB. It extends from the mid-point between Luzon Island and Benham Rise to the Ryukyu Trench south of Miyako Island and then parallels the trench until at least the fore-arc area off Okinawa Island (see Figs. 1 and 2 and map in Hsu et al. 2013). It is difficult to estimate the total offset along the LOFZ because the fossil spreading center west of the fracture zone is entirely subducted beneath the Ryukyu fore-arc and because its location between the northern termination of the CBF rift and the LOFZ is not clear. Based on magnetic identifications, the age of the oceanic crust west of the LOFZ ranges from $54 \mathrm{Ma}$ in the south to younger than $47.5 \mathrm{Ma}$ in the north (Doo et al. 2015). Shinjo and Ishizuka (2015) noticed that all samples collected east of the LOFZ have geochemical plume signatures, contrary to those reported west of the fracture zone. This is a strong argument for a large offset of perhaps several hundred kilometers along that fault zone.

\section{IBM, Yap, and Palau volcanic arcs}

The IBM arc is a $3000 \mathrm{~km}$-long intra-oceanic island arc dated at $\sim 50 \mathrm{Ma}$ (Cosca et al. 1998). It experienced a succession of magmatic episodes accompanying, and recording, subduction initiation as well as several periods of seafloor rifting and spreading. The first spreading phase, at the origin of the West Philippine Basin, was contemporaneous with its initiation and building, probably in interaction with the Oki-Daito mantle plume (Ishizuka et al. 2013). The second phase of spreading, resulting in the Shikoku and Parece Vela basins, split the arc $\sim 25 \mathrm{Ma}$ ago into a remnant arc to the west (the present KPR) and the present IBM arc that remained continuously active. The last spreading episode occurred 2-8 $\mathrm{Ma}$ ago in the Mariana section isolating the West Mariana Ridge to the west from the active Mariana Arc to the east. The oldest evidences of the initial IBM arc consist of gabbros and basalts dated $\sim 51-52 \mathrm{Ma}$, which were found both in the Izu-Bonin fore-arc east of the Bonin Islands (Ishizuka et al. 2008, 2011b) and the Mariana fore-arc south of Guam (Reagan et al. 2013). The stratigraphic section of the fore-arc crust consists, from bottom to top, of peridotites, gabbroic rocks, a sheeted dike complex, basaltic lava flows, lavas and dikes of boninite and their differentiates, transitional high-Mg andesites, and tholeiitic and calc-alkaline arc lavas (Ishizuka et al. 2014). Reagan et al. (2010) named the oldest volcanic products "fore-arc basalts (FABs)", mainly because they are exposed in the present IBM fore-arc. This name is ambiguous because (1) these lavas have geochemical affinities with mid-ocean ridge basalts (MORBs), and (2) because similar lavas of the same age $(\sim 50-52 \mathrm{Ma})$ were drilled during IODP Expedition 351 in the Amami-Sankaku Basin (ADO region) west of the KPR (Arculus et al. 2015). This discovery indicates that the area of initial seafloor spreading contemporaneous with subduction initiation 
extended from the present-day fore-arc to the region west of the present-day KPR (Ishizuka et al. 2015). Observations made in the central Mariana Arc indicate that transitional, and then boninitic lavas, dated $~ 44-$ $48 \mathrm{Ma}$, overlie the FABs, constituting a coherent suite of magmatic rocks characteristic of ophiolite assemblages (Reagan et al. 2010). Variations in $\mathrm{Cr} /(\mathrm{Cr}+\mathrm{Al})$ atomic ratios of spinels in dunites from the IBM "present-day fore-arc" probably reflect changing melt compositions from MORB-like to boninitic melts due to an increase of slab-derived hydrous fluids and/or melts (Morishita et al. 2011). Similarly, transitional suites of high-Mg andesites, dated $\sim 44-45 \mathrm{Ma}$, preceded the eruption of normal tholeiitic to calc-alkaline arc magmatism (Ishizuka et al. 2011b).

Fewer data are available for the Yap and Palau arc systems, but it has been established that the Yap arc is no longer active volcanically since the Late Oligocene or Miocene, right after its collision with the Caroline Ridge (Hawkins and Batiza 1977; McCabe and Uyeda 1983). Fujioka et al. (1996) observed ultramafic and gabbroic rocks along the inner trench slope of the Yap Trench with a paleo-Moho discontinuity around $6000 \mathrm{~m}$ deep. Metamorphic and gabbroic rocks from the Yap Arc appear quite similar to those exposed in the Parece Vela Basin (Ohara et al. 2002). The islands and submerged arc of Palau are thought to be the southern extension of the KPR (Kobayashi 2004). They consist of 20-38 Ma arc-type volcanic rocks including basalt, andesite, and dacite fringed by coral limestones (Meijer et al. 1983).

\section{Constraints and speculations on the subducted portions of the PSP}

\section{The slab beneath the Ryukyu and SW Japan arcs}

A significant part of the PSP has been subducted beneath the Ryukyu Arc as attested by Wadati-Benioff zone seismicity and regional scale tomographic studies (e.g., Bijwaard et al. 1998; Widiyantoro et al. 1999; Wang et al. 2008; Li and van der Hilst 2010; Wei et al. 2012, 2015). A continuous slab-like high-velocity zone (HVZ), dipping roughly $45^{\circ}$, extends beneath the $1200 \mathrm{~km}$-long Ryukyu Arc down to $\sim 300 \mathrm{~km}$ depth. This is consistent with the edge of the seismicity around $250 \mathrm{~km}$ according to Wei et al. (2015), whereas Bijwaard et al. (1998) imaged the high-velocity anomaly deeper, down to at least a 500-600 km depth where it merges with the flat-lying Pacific slab. Lallemand et al. (2001) suspected that the deepest portion of the PSP slab detached during the Upper Miocene - Lower Pliocene east of the Gagua Ridge (Fig. 3). Wei et al. (2015) mentioned that the HVZ extends into the uppermost upper mantle near Taiwan, but only in $\mathrm{V}_{\mathrm{S}}$ tomography, which could suggest that an old and more rigid part of the PSP has penetrated into the lower mantle there. That deep slab could be connected with the detached slab east of the Gagua Ridge (see Fig. 3). Zhao et al. (2012), based on highresolution $\mathrm{P}$-wave tomography, follow the aseismic slab down to $430 \mathrm{~km}$ under Kyushu and $370 \mathrm{~km}$ under southwest Honshu, though the intraslab seismicity ends at $180 \mathrm{~km}$ deep. We thus estimated the downdip length of the PSP aseismic slab beneath SW Japan to be $\sim 700 \mathrm{~km}$ (surprisingly, the authors measure 800$900 \mathrm{~km}$ ). At the scale of the Ryukyu Trench, we will thus hypothesize that the subducted portion of the PSP extends $\sim 700 \mathrm{~km}$ northwestward (Fig. 3). PSP imagery beneath southwest Japan is complicated by the fact that the subducting Shikoku Basin is very young (30-15 Ma) and lies above the old subducting Pacific slab. Cao et al. (2014) confirmed the observation by Zhao et al. (2012) that the P-wave high-velocity anomaly is not continuous beneath southwest Japan. It is apparently interrupted by a low-velocity anomaly north of Kyushu, extending northwestward from $80 \mathrm{~km}$ to greater depths. Huang et al. (2013) and Cao et al. (2014) suggest that the PSP is tearing and forms a slab window corresponding to the KPR. In their model, both the buoyancy of the KPR and the directional change in the motion of the PSP play a role in the tearing process. The corner flow produced by the subducting Pacific slab, together with its dehydration, probably heat the PSP slab from below, thus producing lowvelocity anomalies (Zhao et al. 2012), and hiding the PSP slab dimensions. We will later assume that about $700 \mathrm{~km}$ of PSP slab has been subducted beneath the Ryukyu and southwest Japan arcs.

High intraslab velocity parallel to the trench is consistent with the main spreading direction of the WPB (see grey arrows in Fig. 3). This is also parallel to LOFZ, and may reflect fossil anisotropy (Wei et al. 2015). We thus speculate that the subducted part of the WPB, dextrally offset along the LOFZ, extends beneath the Ryukyu Arc up to the latitude of Kyushu. Indeed, if we simply offset the total width of the WPB measured between the OkiDaito Ridge and the southernmost evidence of WPB oceanic crust (south of the Mindanao FZ), i.e., $2000 \mathrm{~km}$ at most, we conclude that the oceanic crust of the WPB may subduct beneath or south of Kyushu if the LOFZ extends to these latitudes. The ADO region could also extend beneath Kyushu (Fig. 3) but the steep slab observed there rather supports the subduction of an "old" oceanic crust. Park et al. (2009) and Yamamoto et al. (2013) inferred the extent of the KPR beneath the toe of the accretionary prism but the LOFZ could plausibly offset the ridge at a distance of $\sim 200 \mathrm{~km}$ from the trench. The LOFZ could even offset the KPR northward by 150$200 \mathrm{~km}$ (Fig. 3), providing a geometrical explanation to the following. (1) The change in the trend of the seismic slab isopachs from $\mathrm{N} 20^{\circ}$ to $\mathrm{N} 80^{\circ}$ occurs beneath the 


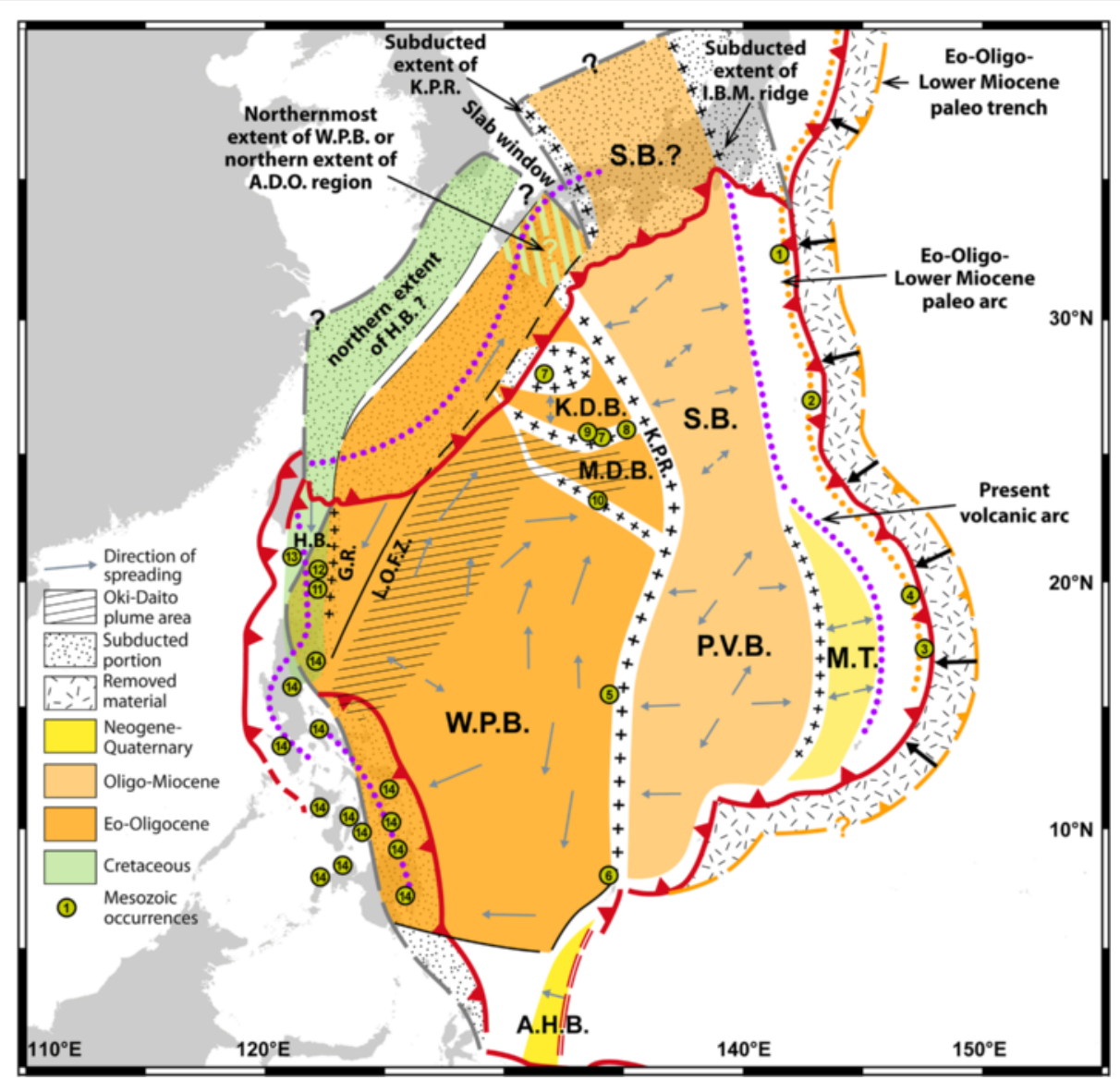

Fig. 3 Oceanic basins with their subducted parts, present and paleo-volcanic arcs and trenches of the PSP. Oceanic basins are outlined with their respective ages and the main directions of spreading (grey arrows). Purple and orange dots indicate the present and Eo-Oligo-Lower Miocene volcanic arcs, respectively, associated with the PSP, either caused by the PSP itself or another plate subducting beneath the PSP. The PSP slabs (dotted areas) have been unfolded and projected at the surface. Note that a small part of the western WPB has subducted beneath the Huatung Basin along the East side of the Gagua Ridge. The location of the Eo-Oligo-Lower Miocene trench (in orange) has been estimated based on the amount of IBM arc consumption by tectonic erosion. Mesozoic terrane occurrences in the PSP are reported with green circles, in which the numbers refer to Table 1 where more details are presented

easternmost part of Honshu and Shikoku islands instead of beneath Kyushu as would be expected if the KPR were not offset. (2) We observe two fore-arc embayments (Fig. 1) that could have resulted from KPR subduction northeast of the present ridge-trench intersection. One is east of Kyushu. It may have been caused by the non-offset ridge segment. The other is south of Shikoku. It might have been caused by the dextrally offset segment. (3) The slab window, described by Huang et al. (2013) and Cao et al. (2014), attributed to a tear along the "weak" KPR is clearly north of the location it would occupy if it were projected along a straight path with no offset. (4) The buoyant KPR might contribute to the shallow-dipping slab beneath southwest Japan (Gutscher and Lallemand 1999) if it is east of the slab window rather than west of it. In this case, the width of the subducted Shikoku Basin would be narrower (Fig. 3).

\section{The slab beneath the Philippine Arc}

The western part of the WPB is also subducting beneath the Philippine Trench. Based on the Wadati-Benioff zone, the slab is no longer than $250 \mathrm{~km}$ at the latitude of Mindanao Island and is shorter both north and south of there (Lallemand et al. 1998). The subduction can be traced from offshore Mortal Island in the south to Luzon Island in the north (Cardwell et al. 1980). The short length of the subducted slab as well arc volcanism ages support a Pliocene age for the start of PSP subduction offshore Mindano. The subduction then propagated both northward and southward (Lallemand et al. 1998). In detail, that region underwent several episodes of subduction, collision, and terrane accretion as depicted by many authors (McCaffrey et al. 1980; Moore and Silver 1982; Hall 1987; Rangin et al. 1999; Pubellier et al. 2004; Hall and Spakman 2015). 
Shortening and even subduction of the WPB probably occurred north of the Philippine Trench along the East Luzon Trough as attested by a negative gravity anomaly and compressional features. Lewis and Hayes (1983) proposed that subduction was active there during the Oligocene. Such short-lived subduction of the WPB along its western margin was also proposed by Deschamps et al. (1998) in the same period with an amplitude decreasing from $200 \mathrm{~km}$ in the south to 0 near the present intersection between the Gagua Ridge and the Ryukyu Trench (see Fig. 3). Transpression along the Gagua Ridge has been also proposed by Eakin et al. (2015) but during the lower Miocene rather than the Oligocene.

\section{Estimating margin loss by tectonic erosion along the IBM Arc}

Convergent margins are generally the locus of mass transfers from one plate to the other across the plates' interface. Accretion of crust or sediment may occur, contributing to a net growth of the upper plate, but sedimentary or crustal erosion (also called tectonic erosion) is also possible, resulting in a net loss of upper plate material. Von Huene and Scholl (1991) estimated that about half of the convergent margins were accreting and half were erosive. There are two main indicators for a net global loss of crust at a convergent margin: a significant fore-arc subsidence increasing trenchward together with a landward retreat of the active volcanic front (von Huene and Lallemand 1990; Lallemand 1995). Most of the time, the two indicators are observed to be simultaneous (Fig. 4). Since the PSP is subducting along its western boundaries, we will focus on its eastern limit, which includes the IBM, Yap and Palau margins, to determine whether the plate has grown or shrunk.

\section{IBM arc-trench system}

The trench-arc distance varies from $\sim 200 \mathrm{~km}$ along the Izu-Bonin to less than $200 \mathrm{~km}$ in the Mariana subduction zones. The Pacific slab always dips more than $50^{\circ}$ and can even reach $\sim 90^{\circ}$ beneath the central Mariana Arc. The Pacific plate carries numerous seamounts (Fig. 1) into the subduction zone all along that trench (Fryer and Smoot 1985) favoring the dismantlement, weakening and subsequent consumption of the margin's front (e.g., Lallemand et al. 1994, Dominguez et al. 1998, von Huene et al. 2004). As a consequence, the trench inner slope is steep and no sediment accretion is observed at the toe of the margin. Instead, basement rocks have been drilled close to the trench and even serpentinite mud volcanoes have been observed all along the Mariana fore-arc (Natland and Tarney 1981; Bloomer 1983; Fryer 1992; Lagabrielle et al. 1992b; Fryer et al. 1999). The diversity of metabasic rocks found in one of these seamounts can be explained by recycling of forearc materials through tectonic erosion and subduction of the fore-arc (Fryer et al. 2006). The IBM margin has been classified as one of the most erosive margins in the world (e.g., von Huene and Scholl 1991; Lallemand 1995). Subsidence of the fore-arc of more than $2 \mathrm{~km}$ since $\sim 40 \mathrm{Ma}$ in the Izu-Bonin fore-arc and $\sim 24 \mathrm{Ma}$ in the Mariana fore-arc has been documented thanks to benthic foraminifers contained in sediment cores that are able to record paleo-bathymetry (Kaiho 1992; Lagabrielle et al. 1992a). In parallel research, Mitchell et al. (1992) reported volcanic rock outcrops from 17 to $41 \mathrm{Ma}$ at a distance of $\sim 50 \mathrm{~km}$ from the Izu-Bonin Trench, indicating that the volcanic front has retreated by at least $150 \mathrm{~km}$ during the last $41 \mathrm{Ma}$ (Fig. 4). A similar history is documented in the Mariana fore-arc with gabbros and 30-45 Ma volcanic rocks outcropping near the trench, supporting a retreat of the volcanic arc

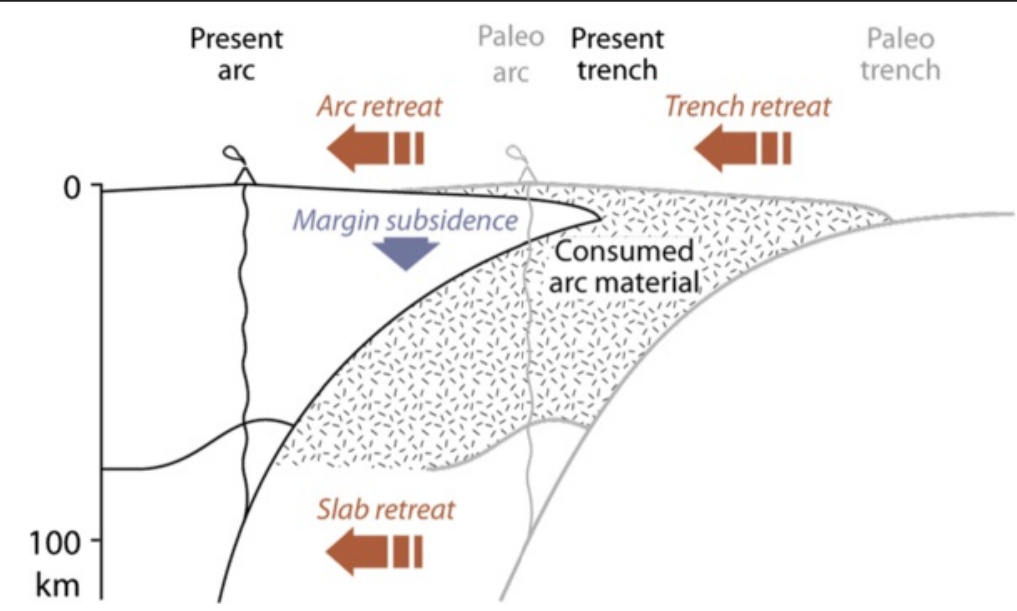

Fig. 4 Sketch showing the shrinking of an active margin undergoing tectonic erosion. Black and grey lines, respectively, outline the present and reconstructed slab's top and upper plate geometries with respect to a reference line that could be the present volcanic arc 
of at least $150 \mathrm{~km}$ (Hussong and Uyeda 1981; Bloomer 1983) (Fig. 4). Johnson et al. (2014) analyzed plutonic rocks from two dredge sites along a normal fault scarp off Guam very close to the trench. These rocks were created from boninite parental magmas that were modified into tonalites and are now part of a midcrustal layer. Their exposure near the trench is another evidence of tectonic erosion processes.

Volcanic arc retreat sometimes results from a shallowing of slab dip, but in this case, and especially in the Mariana Arc, the present-day slab dip is almost vertical. Assuming that it has been continually vertical, which is unlikely, the margin's front has retreated by at least $150 \mathrm{~km}$ through consumption of the material constituting the lower section of the margin following a mechanism depicted in Lallemand et al. (1992) or Lallemand (1998). This appraisal is extremely conservative, and a more realistic estimate would consider the margin's retreat to be at least $200 \mathrm{~km}$ because the slab dip was probably shallower in the past and because the oldest record of arc activity recovered in the fore-arc is younger than the presumed arc initiation at $\sim 52 \mathrm{Ma}$ (see section 1.5; Ishizuka et al. 2011a). By extension, the whole margin, from southern Mariana to northern Japan has been severely affected by tectonic erosion processes during the Neogene and maybe earlier (Lallemand 1995, 1998). The Eo-Oligo-Lower Miocene paleo-arc is located a very short distance from the trench, varying from a few kilometers in the Mariana fore-arc to $90 \mathrm{~km}$ in northern Japan where the volcanic arc retreated by $\sim 210 \mathrm{~km}$ during the last $23 \mathrm{Ma}$. This retreat occurred simultaneously with a subsidence of the margin by more than $6 \mathrm{~km}$ (von Huene and Lallemand 1990). We can thus extend the eastern boundary of the Paleogene PSP by at least $200 \mathrm{~km}$ eastward (Fig. 3).

\section{Southernmost Mariana and Yap trench systems}

The southernmost Mariana Arc and Yap segments have undergone a different story because the southernmost Mariana arc-trench system stretched E-W in response to the arc indentation of the Caroline Ridge at $\sim 23 \mathrm{Ma}$, the spreading of the Parece Vela Basin and the Mariana Trough (Fujiwara et al. 2000; Martinez et al. 2000; Stern et al. 2013). The activity of the Yap Arc ceased after collision with the Caroline Ridge (McCabe and Uyeda 1983) and strong tectonic erosion narrowed the trench paleo-arc distance to $\sim 50 \mathrm{~km}$. As a consequence, lower crustal and even upper mantle sections of the PSP are exposed on the inner slope of the Yap Trench (Fujiwara et al. 2000). Significant arc consumption occurred there at least during the Neogene.

This observation is extremely important for correctly interpreting the petrological and chronological data collected along that arc.

\section{Evidences for Jurassic and Cretaceous relics of the proto-PSP}

Most of the PSP consists of Eocene or younger magmatic or sedimentary rocks formed or deposited after its inception, but from the early beginning of PSP exploration, several evidences of older crust have been reported (see Table 1), attesting to the existence of a Jurassic to Early Cretaceous "proto-PSP" (e.g., Ingle et al. 1975; Matsuda et al. 1975; Hussong and Uyeda 1981).

We distinguish between two types of Mesozoic rock occurrences in the PSP depending on their location within, or along, the edges of the PSP. Some were observed in a central position like the ADO region. They necessarily belong to the proto-PSP. Others were observed near the plate boundaries, i.e., along the IBM arc or Huatung Basin. They might have been accreted after the PSP formed.

Starting with the ADO region, Matsuda et al. (1975) reported Late Cretaceous $\mathrm{K}$-Ar ages for whole-rock hornblende tonalites and basalts dredged from the Amami Plateau (7 in Table 1 and Fig. 3). Hickey-Vargas (2005) performed ${ }^{40} \mathrm{Ar} /{ }^{39} \mathrm{Ar}$ dating on those tonalites and obtained an Early Cretaceous age ( 115-118 Ma) that could be attributed to subsequent reheating or another Ar-loss event. Based on the geochemical characteristics of the basalts, she concluded that the Early Cretaceous subduction zone that formed the Amami Plateau might have been the site of slab melting compatible with the subduction of a young, hot plate at that time. The Amami tonalites were probably formed by fractional crystallization from the basaltic magma or partial melting of basaltic arc crust. Mizuno et al. (1978) and Okino and Kato (1992) mentioned that the Daito and Oki-Daito ridges (10 in Table 1 and Fig. 3) consisted of pre-Eocene basement rocks overlain by middle Eocene sedimentary rocks. More recently, andesites dredged on the Daito Ridge (8 and 9 in Table 1 and Fig. 3) returned ${ }^{40} \mathrm{Ar} /{ }^{39} \mathrm{Ar}$ ages of $\sim 116-119 \mathrm{Ma}$ (Ishizuka et al. 2011a). Tani et al. (2012) revealed after analyzing samples collected during a diving cruise conducted in 2010 that the ADO region dominantly exposed deep crustal sections of gabbroic, granitic, and metamorphic rocks with possible continental affinities. Jurassic to Cretaceous zircon $\mathrm{U}-\mathrm{Pb}$ ages have been obtained from the plutonic rocks ( 7 in Table 1 and Fig. 3).

Today, the KPR occupies a central position but it constituted the proto-IBM arc and rear-arc before the opening of the Shikoku and Parece Vela basins. As discussed in section 3, tectonic erosion processes have consumed the margin's front, at least during the Neogene. We thus consider that Cretaceous ages obtained from a volcanic apron west of the KPR (Ingle et al. 1975; 5 in Table 1 and Fig. 3) or in its southernmost part (Ishizuka et al. 
Table 1 List of samples collected in the PSP providing evidence for a pre-Eocene proto-PSP

\begin{tabular}{|c|c|c|c|c|}
\hline Region (see $n^{\circ}$ in Fig. 3) & Sample location & Sample nature and dated material & Estimated age & Source \\
\hline \multicolumn{5}{|l|}{ Izu-Bonin fore-arc } \\
\hline \multirow[t]{2}{*}{1} & \multirow[t]{2}{*}{ Dive samples (YK11-07) $32^{\circ} 14^{\prime} \mathrm{N}-141^{\circ} 39^{\prime} \mathrm{E}$} & \multirow[t]{2}{*}{ Andesite, diorite } & \multirow{2}{*}{$\begin{array}{l}\text { Cretaceous } \sim 100 \mathrm{Ma}(\mathrm{U}-\mathrm{Pb})+\text { Paleozoic } \\
\text { and Proterozoic detrital zircons }\end{array}$} & Tani et al. 2012 \\
\hline & & & & Tani and Myojinsho 2011 \\
\hline \multirow[t]{2}{*}{2} & \multirow[t]{2}{*}{ Sample 6 K1152 $27^{\circ} 19^{\prime} \mathrm{N}-143^{\circ} 00^{\prime} \mathrm{E}$} & \multirow[t]{2}{*}{ Two pillow basalt lavas beneath gabbro } & \multirow[t]{2}{*}{ Middle Jurassic $159.4 \pm 0.9 \mathrm{Ma}\left({ }^{40} \mathrm{Ar} /{ }^{39} \mathrm{Ar}\right)$} & Ishizuka et al. $2011 \mathrm{~b}$ \\
\hline & & & & Ishizuka et al. 2012 \\
\hline \multicolumn{5}{|l|}{ Mariana fore-arc } \\
\hline 3 & Site 460 , DSDP $6017^{\circ} 40^{\prime} \mathrm{N}-147^{\circ} 35^{\prime} \mathrm{E}$ & $\begin{array}{l}\text { Pebble conglomerate with Calpionella } \\
\text { alpina }\end{array}$ & $\begin{array}{l}\text { Late Jurassic to Early Cretaceous ( 130- } \\
140 \mathrm{Ma})\end{array}$ & Azéma and Blanchet 1981 \\
\hline 3 & Site $46017^{\circ} 40^{\prime} \mathrm{N}-147^{\circ} 35^{\prime} \mathrm{E}$ & Reworked radiolarians & $\begin{array}{l}\text { Upper Cretaceous (Campanian, 72-83 } \\
\text { Ma) }\end{array}$ & Hussong and Uyeda 1981 \\
\hline 3 & Site $46117^{\circ} 46^{\prime} \mathrm{N}-147^{\circ} 41^{\prime} \mathrm{E}$ & Reworked radiolarians & "Cretaceous" ( 65-135 Ma) & Hussong and Uyeda 1981 \\
\hline 4 & Dredges $19^{\circ} 37^{\prime} \mathrm{N}-147^{\circ} 04^{\prime} \mathrm{E}$ & Radiolarian cherts & $\begin{array}{l}\text { Lower Cretaceous Valanginian } \sim 97-112 \\
\text { Ma and Albian 131-138 Ma }\end{array}$ & Johnson et al. 1991 \\
\hline 4 & Dredges $19^{\circ} 37^{\prime} \mathrm{N}-147^{\circ} 04^{\prime} \mathrm{E}$ & Foraminifers in cherts & $\begin{array}{l}\text { Lower Cretaceous (Aptian to Albian 96- } \\
113 \mathrm{Ma} \text { ) }\end{array}$ & Johnson et al. 1991 \\
\hline 4 & Dredges $19^{\circ} 37^{\prime} \mathrm{N}-147^{\circ} 04^{\prime} \mathrm{E}$ & MORB metabasalt & Upper Cretaceous $85 \mathrm{Ma}$ (K-Ar) & Johnson et al. 1991 \\
\hline 4 & Dredges $19^{\circ} 37^{\prime} \mathrm{N}-147^{\circ} 04^{\prime} \mathrm{E}$ & Highly metamorphosed alkali basalt & Upper Cretaceous $71 \mathrm{Ma}$ (K-Ar) & Johnson et al. 1991 \\
\hline \multicolumn{5}{|l|}{ WPB } \\
\hline 5 & Site 290 east of $\mathrm{KPR} 17^{\circ} 44^{\prime} \mathrm{N}-133^{\circ} 28^{\prime} \mathrm{E}$ & $\begin{array}{l}\text { Reworked foraminifers in a volcaniclastic } \\
\text { apron }\end{array}$ & Cretaceous & Ingle et al. 1975 \\
\hline \multicolumn{5}{|l|}{ KPR } \\
\hline 6 & $\begin{array}{l}\text { Dredge in southernmost part of KPR on } \\
\text { a ridge between Palau Trench and KPR }\end{array}$ & $\begin{array}{l}\text { Mafic schists of amphibolite to } \\
\text { greenschists facies }\end{array}$ & $\begin{array}{l}\text { May have similar age and origin to } \\
\text { Cretaceous Daito Ridge }\end{array}$ & Ishizuka et al. 2012 \\
\hline \multicolumn{5}{|l|}{ ADO region } \\
\hline \multirow[t]{4}{*}{7} & Dive samples (YK10-04) & \multirow{4}{*}{$\begin{array}{l}\text { Gabbroic, granitic and metamorphic } \\
\text { rocks }\end{array}$} & \multirow[t]{4}{*}{ Jurassic to Cretaceous magmatic zircons } & Tani et al. 2012 \\
\hline & $25^{\circ} 54^{\prime} \mathrm{N}-133^{\circ} 54^{\prime} \mathrm{E}$ & & & Tani 2010 \\
\hline & $27^{\circ} 53^{\prime} \mathrm{N}-131^{\circ} 51^{\prime} \mathrm{E}$ & & & \\
\hline & $27^{\circ} 56^{\prime} \mathrm{N}-132^{\circ} 02^{\prime} \mathrm{E}$ & & & \\
\hline \multicolumn{5}{|l|}{ Amami Plateau } \\
\hline \multirow[t]{3}{*}{7} & \multirow[t]{3}{*}{ Dredge $11-17-128.07^{\circ} \mathrm{N}-131.63^{\circ} \mathrm{E}$} & \multirow[t]{3}{*}{ Hornblende tonalite } & \multirow{3}{*}{$\begin{array}{l}\text { Lower Cretaceous } 69.5 \mathrm{Ma}(\mathrm{K} / \mathrm{Ar})-117.0 \pm \\
1.1 \mathrm{Ma}\left({ }^{40} \mathrm{Ar} /{ }^{39} \mathrm{Ar}\right)\end{array}$} & Matsuda et al. 1975 \\
\hline & & & & Tokuyama 1985 \\
\hline & & & & Hickey-Vargas 2005 \\
\hline \multirow[t]{3}{*}{7} & \multirow[t]{3}{*}{ Dredge $11-17-528.08^{\circ} \mathrm{N}-132.02^{\circ} \mathrm{E}$} & \multirow[t]{3}{*}{ Hornblende tonalite } & \multirow{3}{*}{$\begin{array}{l}\text { Lower Cretaceous } 75.1 \mathrm{Ma}(\mathrm{K} / \mathrm{Ar})-115.8 \pm \\
0.5 \mathrm{Ma}\left({ }^{40} \mathrm{Ar}{ }^{39} \mathrm{Ar}\right)\end{array}$} & Matsuda et al. 1975 \\
\hline & & & & Tokuyama 1985 \\
\hline & & & & Hickey-Vargas 2005 \\
\hline
\end{tabular}


Table 1 List of samples collected in the PSP providing evidence for a pre-Eocene proto-PSP (Continued)

Daito Ridge

Oki-Daito Ridge

10

11

12

13

Philippine archipelago

14

Short core or dredge $\sim 25.9^{\circ} \mathrm{N}-135.2^{\circ} \mathrm{E}$

Short core or dredge $\sim 26.0^{\circ} \mathrm{N}-133.1^{\circ} \mathrm{E}$

Andesite

Andesite

Alkali basalt

Gabbro

Gabbro

Dredged sample RD20 $21.49^{\circ} \mathrm{N}-122.69^{\circ} \mathrm{E}$

YehYu Creek sample on Lanyu Island $22^{\circ} \mathrm{N}-121.55^{\circ} \mathrm{E} \quad$ Red chert float radiolarian

Outcrops
Upper Cretaceous 82.4 and 85.1 Ma (K/Ar)

Matsuda et al. 1975

Tokuyama 1985

Lower Cretaceous $116.9 \pm 0.9 \mathrm{Ma}\left({ }^{40} \mathrm{Ar} /{ }^{39} \mathrm{Ar}\right) \quad$ Ishizuka et al. 2011a

Lower Cretaceous

Ishizuka et al. 2011 a

$118.9 \pm 0.4 \mathrm{Ma}\left({ }^{40} \mathrm{Ar} /{ }^{39} \mathrm{Ar}\right)$

Limit Upper Cretaceous-Paleocene $65 \mathrm{Ma}$

Okino and Kato 1992

Lower Cretaceous

Deschamps et al. 2000

$121.2 \pm 4.6 \mathrm{Ma}\left({ }^{40} \mathrm{Ar} /{ }^{39} \mathrm{Ar}\right)$

Lower Cretaceous

Deschamps et al. 2000

$123.2 \pm 7.8 \mathrm{Ma}\left({ }^{40} \mathrm{Ar} /{ }^{39} \mathrm{Ar}\right)$

Lower Cretaceous (Barremian 113-117 Ma) Deschamps et al. 2000

Cretaceous

Yumul 2007 
2012; 6 in Table 1 and Fig. 3) are representative of the proto-PSP prior to its isolation.

Closer to the trench, Mesozoic rocks have also been discovered along the IBM fore-arc since Deep-Sea Drilling Project (DSDP) expeditions in 1978 (Hussong and Uyeda 1981; Bloomer 1983). Late Cretaceous reworked radiolarians and Upper Jurassic Calpionellids were observed in cherts drilled at sites 460 and 461 in the Mariana fore-arc (Azéma and Blanchet 1981; 3 in Table 1 and Fig. 3). At distances of $\sim 200 \mathrm{~km}$ north of these sites and more than $50 \mathrm{~km}$ arcward of the trench (4 in Table 1 and Fig. 3), dredged cherts, mafic and intermediate lavas, and intrusive rocks documented the presence of an ophiolite suite interpreted by Johnson et al. (1991) as accreted fragments of a Cretaceous oceanic plate. The volcanic rocks provided Late Cretaceous K-Ar ages, while the radiolarians and foraminifers supported an early Cretaceous age ( 97-138 Ma). More recently, volcanic rocks have been also sampled in the northern part of the IBM fore-arc. East of the Bonin Islands, pillow-lavas were dated at $159.4 \pm 0.9 \mathrm{Ma}\left({ }^{40} \mathrm{Ar} /{ }^{39} \mathrm{Ar}\right.$, Ishizuka et al. 2011b; 2 in Table 1 and Fig. 3), while andesites and diorites east of Aogashima Island gave Cretaceous ( $100 \mathrm{Ma}) \mathrm{U}-\mathrm{Pb}$ magmatic ages and abundant Paleozoic to Proterozoic detrital zircons (Tani et al. 2012; 1 in Table 1 and Fig. 3). Such "continental" zircons, together with the Indian MORB-like isotopic characteristics of the Jurassic lavas in the Bonin islands region, are substantial evidences for a proto-PSP origin in the vicinity of a continent (Tani et al. 2012; Ishizuka et al. 2012), rather than the allochtonous accreted fragments of Pacific origin proposed in the Mariana fore-arc by Bloomer (1983) or Johnson et al. (1991).

As discussed in section 1.2, the age of the Huatung Basin is controversial but we cannot ignore new datings obtained by Deschamps et al. (2000) on gabbros dredged in 1980 during a Research Vessel Vema cruise (Mrozowski et al. 1982). The two dredge sites are located on basement highs west of the Gagua Ridge (11 and 12 in Table 1 and Fig. 3). They provided Early Cretaceous ${ }^{40} \mathrm{Ar} /{ }^{39} \mathrm{Ar}$ ages of $\sim 115-131 \mathrm{Ma}$. Furthermore, $\sim 113-117 \mathrm{Ma}$ radiolarians were discovered in several red chert float samples, probably collected during the Tungchin andesitic eruption on Lanyu Island (13 in Table 1 and Fig. 3). These cherts likely belonged to the former oceanic plate (Huatung Basin) on which the Miocene volcanic arc was built (Deschamps et al. 2000). Hickey-Vargas et al. (2008) analyzed the two gabbros and concluded that they have an Indian MORB Hf-Nd isotopic signature, with $\mathrm{Pb}$ isotope ratios intermediate but closer to Pacific MORBs than the WPB, which has a strong Indian $\mathrm{Pb}$ isotope signature. For comparison, sources for igneous rocks from the Amami Plateau, thought to be an Early Cretaceous island arc, have Indian $\mathrm{Hf}$ and $\mathrm{Nd}$ (presubduction mantle) and Pacific $\mathrm{Pb}$ (subduction component) isotope characteristics (Hickey-Vargas et al. 2008).

Except in its northernmost part (north Luzon and the Batan islands), the Philippine archipelago does not belong to the present-day PSP, but before the inception of the Philippine Trench in the Late Miocene, it can be considered to have been part of the PSP. The Philippine region has a composite basement containing numerous ophiolite complexes, most of them being of supra subduction origin (Pubellier et al. 2004). Based on gravity data, these authors suggested that the present Miocene volcanic arc in Luzon lies directly on the southern extension of the Huatung Basin. Yumul (2007) provided a compilation of ophiolites all along the mobile belt. Except in a few places, like Zambales or Amnay, most of them are Jurassic to Cretaceous in age (14 in Table 1 and Fig. 2). He proposed a zonation from Late Cretaceous amphibolites with quartz-albite metamorphic soles distributed mainly in the eastern belt, then Early to Late Cretaceous dismembered ophiolites with mostly tectonic melanges in the central belt and finally Late Cretaceous to Oligocene ophiolitic complexes in the western belt. Such a zonation is discussed by Tani et al. (2015), who obtained new zircon ages from the northern ophiolite belts. They showed these to be Eocene in age and thus probably genetically associated with the WPB opening. As for the southern ophiolites, in Cebu, Lagonoy and Dinagat, gabbroic and leucocratic rocks associated with the ophiolitic complexes are Jurassic to Late Cretaceous in age ( 90-200 Ma). Tani et al. (2015) then concluded that these Mesozoic ophiolites from the southern Philippines may potentially be correlated with the Mesozoic arc and ophiolitic rocks of the ADO region before the WPB opening.

\section{Early Eocene isolation of the PSP through subduction initiation along the proto-IBM Arc}

The geodynamic context of the proto-PSP isolation has long been a matter of debate. The orthogonality of the CBF rift with the KPR was first interpreted as an indication of plate entrapment. It was proposed that the WPB resulted from a segment of the Kula-Pacific Ridge and associated oceanic crust being trapped in the Middle Miocene (Uyeda and Ben Avraham 1972; Uyeda and McCabe 1983; Hilde and Lee 1984). A variant of this model was later proposed by Jolivet et al. (1989), who posited that a piece of the North New Guinea/Pacific Ridge was trapped during the Middle Eocene. Lewis et al. (1982) first proposed a back-arc origin for the formation of the WPB behind the East Mindanao-Samar Arc. Other authors have also suggested that the WPB opened as a back-arc basin either behind the East MindanaoSamar Arc (Rangin et al. 1990; Lee and Lawver 1995) or the proto-IBM Arc (Seno and Maruyama 1984) but with 
poor constraints on the timing and kinematics of these events. Based on considerable geological and paleomagnetic constraints, especially those imposed from ocean drilling data and the Philippine islands, Hall et al. (1995a,b,c) were the first to propose that the proto-PSP was isolated between two opposing-vergent subduction zones, and then rotated clockwise while migrating north from its initial position near the equator. Hall (2002) later refined the plate tectonic evolution of the whole western Pacific region. Deschamps and Lallemand (2002) used Hall's model when providing more details on the WPB spreading processes. In the earlier stages of WPB opening, they have accounted for the presence of a plume (Macpherson and Hall 2001) in the generation of the Benham Rise, Urdaneta Plateau, numerous overlapping spreading centers and ridge jumps. The existence of this plume, called the "Oki-Daito" plume by Ishizuka et al. (2013), is supported by numerous petrologic (e.g., Hickey-Vargas 1998) and structural (e.g., Deschamps and Lallemand 2002; Deschamps et al. 2008) studies. The updated ages and relative symmetry of the WPB opening have allowed us to refute the "entrapment model" and definitely consider the WPB as having been formed between two facing subduction zones, the East Mindanao-Samar, also called the proto-Philippine, and the proto-IBM.

\section{Constraints on the age of PSP inception}

The age of the shift from proto-PSP to PSP is reasonably constrained if we accept that the inception of the IBM subduction establishes the birth of the PSP. However, this point needs to be clarified because, if most authors agree that the inception of IBM subduction marked the onset of the PSP, there is still a debate about the best marker for subduction initiation. Ishizuka et al. (2011b) relates the onset of fore-arc basalt (FAB) magmatism, at 51-52 Ma with the age of initiation of (Pacific) slab sinking, because they are the oldest lavas present on the arc that are genetically linked with the magma suite observed from the Mariana to the Izu-Bonin fore-arc. From a petrological point of view, most authors (e.g., Stern and Bloomer 1992; Stern et al. 2012; Reagan et al. 2010; Ishizuka et al. 2011b) consider that the FABs erupted in a fore-arc position close to the paleo-trench, but we proposed in section 3 that $200 \mathrm{~km}$ of the margin's front has been removed since the onset of subduction, putting the FABs at a significant distance from the incipient trench at the time of their eruption. This initial setting was recently confirmed during IODP Exp. 351 with the discovery of rocks similar to the FABs in the Amami-Sankaku Basin, $\sim 250 \mathrm{~km}$ west of the present-day trench ( $400-450 \mathrm{~km}$ west of the paleo-incipient trench), which account for the Shikoku Basin opening (Fig. 2, Ishizuka et al. 2015). The seismic structure of the
KPR indicates that the igneous basement of the AmamiSankaku Basin, characterized by FABs, continues beneath the ridge, showing that the earliest arc lies above the FABs (Arculus et al. 2015). Moreover, FABs are MORB-like tholeiitic basalts showing little or no mass transfer from a subducting plate (Reagan et al. 2010). Consequently, the argument that the occurrence of FABs should date the inception of IBM subduction no longer stands. By contrast, the first occurrence of boninites, which required a source of volatiles, certainly marks the subduction of a hydrated lithosphere. We thus conclude that the Pacific crust reached a significant depth and metasomatized the overlying mantle at $\sim 49-48 \mathrm{Ma}$. Considering that the transition from strike-slip movement along a transform boundary to convergent movement would unlikely produce high convergence rates (normal to the boundary) in the earlier stages, subduction inception would reasonably have started a few m.y. earlier, i.e., $~ 52-50 \mathrm{Ma}$ is probably a minimum age. Thus we finally converge with the estimate by Ishizuka et al. (2011b) using a different marker for the onset of IBM subduction.

Deschamps and Lallemand (2002), based on the characteristics of the seafloor between the ODE and the OkiDaito Ridge, estimated the rifting of the WPB to have occurred around $55 \mathrm{Ma}$ with a start of spreading at $\sim 54 \mathrm{Ma}$. This oldest age for the WPB crust has been confirmed by Doo et al. (2015). Since there was no IBM subduction when the WPB rifted and spreading began, we should consider that it started to open behind the proto-Philippine Arc under the influence of the Oki-Daito plume.

\section{Possible trigger for PSP inception}

With respect to what triggered the IBM and thus PSP inception, the following has been documented. (1) The Pacific plate changed its motion at $43-50 \mathrm{Ma}$ (Steinberger et al. 2004; Sharp and Clague 2006; Wessel et al. 2006; Whittaker et al. 2007). Consequently, the timing of this major event is much younger than the initiation of subduction along the proto-IBM trench prior to $50 \mathrm{Ma}$. Furthermore, Faccenna et al. (2012) showed that the slab pull force that grew along the IBM (and Tonga-Kermadec) subduction zone largely contributed to the Pacific plate motion change. (2) The Oki-Daito plume has also been proposed as another candidate for subduction initiation but again, the oldest rocks with OIB affinities, which were found in the Minami-Daito Basin, were dated $48.4 \mathrm{Ma}$ (Ishizuka et al. 2013), following the proto-IBM subduction by no less than 3 m.y. Faccenna et al. (2010) proposed that the plume might have resulted from the concomitant return mantle flow generated by the two facing subduction zones following a scenario similar to those of the present North Fiji Basin. Ishizuka et al. (2013) ruled this hypothesis out considering that the mantle 2 OIB enrichment, which persisted over 15 m.y., has the 
characteristics of a very depleted mantle and does not show evidence of an enriched plume. Plume-induced subduction initiation has been invoked by Gerya et al. (2015) based on a hotter early Earth, but in a colder Earth where plate tectonics is ongoing, one may consider that the basal drag that the plume exerted below the plates might have altered the small proto-PSP motion. (3) Spontaneous subduction involving the vertical sinking of older, denser lithosphere along a transform-fracture system, as proposed by many authors (e.g., Karig 1982; Stern and Bloomer 1992; Shervais and Choi 2011) can also be ruled out. First of all, reasonable numerical models indicate that compression across the boundary fault is required (e.g., Toth and Gurnis 1998; Gurnis et al. 2004; Leng and Gurnis 2011; Leng et al. 2012) and the classical mode of failure of lithosphere under compression is localization of the deformation along conjugated shear bands dipping at an angle of $\sim 50^{\circ}$, then failure along one of them and thrust development (e.g., Shemenda 1992). The theoretical conditions used in numerical models to initiate a "spontaneous" gravitational sinking lithosphere require an extremely young (newly formed) upper plate separated from an old, dense oceanic plate by a very weak boundary zone and sometimes even a no-slip condition on the down-going plate (Gerya et al. 2008; Gerya 2012; Leng and Gurnis 2015). Secondly, no present or recent subduction onsets, the Philippine, New Hebrides, Flores or Wetar trench, for example, have involved such gravitational scenarios. All these recent incipient subductions required compressional tectonic forces to initiate them (Hall et al. 2003; Lallemand et al. 2005). Thirdly, transpression along a former transform boundary between two oceanic plates may allow the younger plate to subduct beneath the older as presently observed along the Hjort Trench (Meckel et al. 2005). (4) The most reasonable trigger is the subduction of the Izanagi-Pacific (IP) Ridge beneath Asia at $60-55 \mathrm{Ma}$ (Whittaker et al. 2007; O'Connor et al. 2013; Seton et al. 2015). Rapid subduction of the still-spreading IP ridge, over a vast distance, likely triggered a chain reaction of tectonic plate reorganization (Fig. 5). Ridge-push and slab pull forces acting on the Pacific plate changed drastically, resulting in a switch of the absolute motion from northwest to west-directed around $55 \mathrm{Ma}$. Since the Australian plate absolute motion also changed during the same period (Whittaker et al. 2007), subduction systems initiated along the Tonga-Kermadec and IzuBonin-Mariana fracture zones where convergence localized (Hall et al. 2003). The potential giant Izanagi slab detachment is thought to have changed not only plate-driven forces such as slab pull or ridge-push, but also affected the sub-Pacific and sub-East Asia mantle flow. As such, this mega-event could have also contributed to the occurrence of the Oki-Daito mantle plume accompanying the newly formed IBM subduction zone. The mechanism would reasonably be a return flow triggered by a combination of factors including the two facing subduction zones (Faccenna et al. 2010) and the

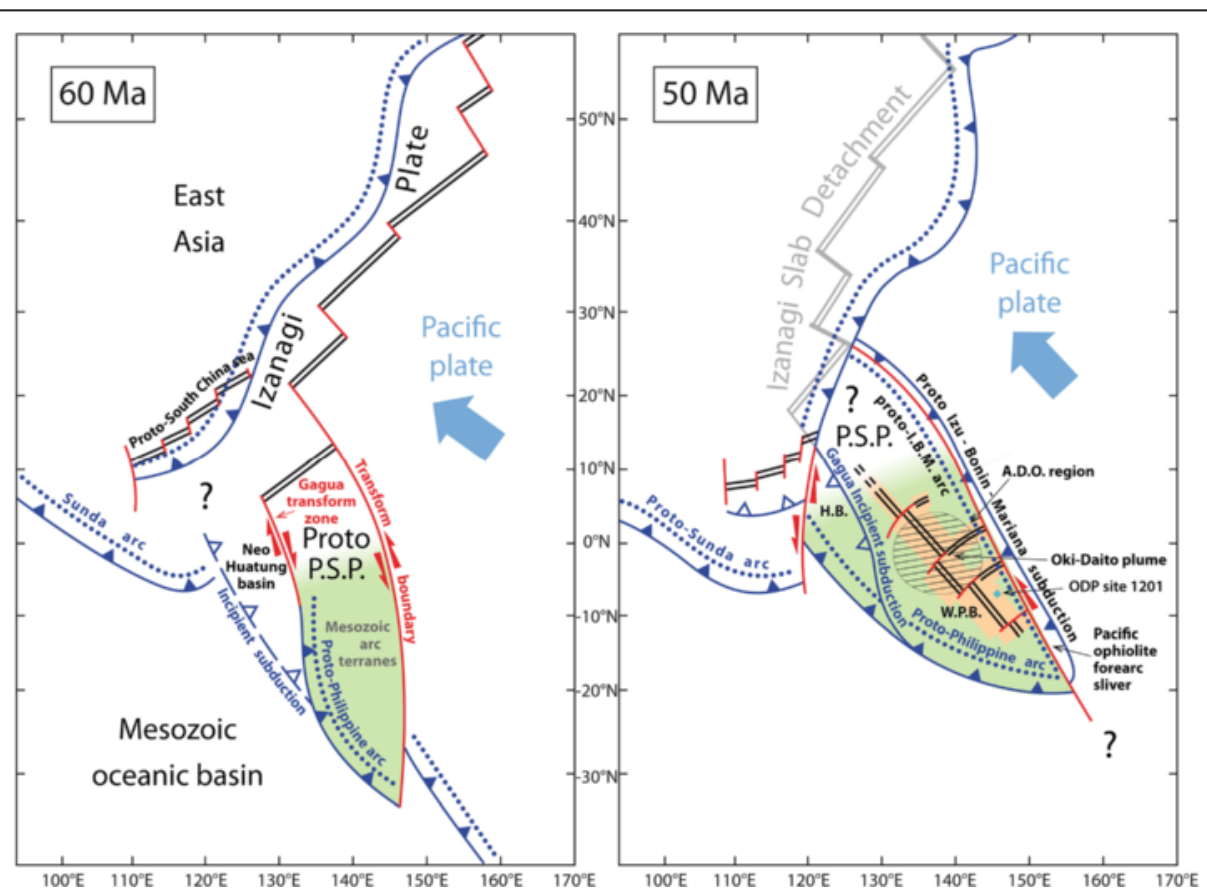

Fig. 5 Geodynamic environment of the proto-PSP at $60 \mathrm{Ma}$ and the PSP at $50 \mathrm{Ma}$. This figure has been modified after Seton et al. (2015). H.B. Huatung Basin. Mesozoic arc terranes are in green and the newly formed oceanic basins are in orange 
sinking of the detached Izanagi slab on another side (see Fig. 5).

\section{Reconstructed PSP paleo-kinematics}

Based on convergent paleomagnetic results, there is a relative consensus on the paleolatitude of the proto-PSP near the equator (Fig. 5, Hall et al. 1995a,b,c). For many years, interpretation of paleomagnetic results has been controversial because declination data have been obtained only from the eastern margin, where subductionrelated tectonic processes may have caused local, rather than plate-wide, rotations (Hall et al. 1995c). Based on ODP site 1201, drilled $\sim 100 \mathrm{~km}$ west of the KPR and $\sim 450 \mathrm{~km}$ north of the CBF rift, Richter and Ali (2015) produced new data on the PSP drift since the Middle Eocene. They have analyzed the WPB basaltic basement $(\sim 47 \mathrm{Ma})$ and its overlying sedimentary sequence. Paleolatitudes derived from the sedimentary sequence support the model of northward movement of the plate since the Eocene. The basaltic basement lay at $\sim 7 \pm 5^{\circ} \mathrm{S}$ in the Middle Eocene (see ODP site 1201 on Fig. 5, to be compared with $19^{\circ} 18^{\prime} \mathrm{N}$ today). The paleolatitudes determined from site 1201 are consistent with northward movement of the plate as predicted by Hall (1997) or Queano et al. (2007) and as determined by earlier paleomagnetic investigations on drill cores or from onland formations. The PSP decelerated between 50 and $20 \mathrm{Ma}$ with a minimum plate movement at $20 \mathrm{Ma}$. Any rotational component of the plate is hard to extract since the deep-sea cores are not oriented and most azimuthally oriented paleomagnetic data are from plate boundary zone islands, potentially subject to local rotations. Based on drill cores obtained in the ADO region, Yamazaki et al. (2010) considered that most of the northward shift was accomplished between about 50 and $25 \mathrm{Ma}$ with very little northward movement after $15 \mathrm{Ma}$. They also present a model in which the PSP rotated $90^{\circ}$ clockwise between 50 and $15 \mathrm{Ma}$ around an Euler pole near $23^{\circ} \mathrm{N} 162^{\circ} \mathrm{E}$. Deschamps and Lallemand (2002) used Hall's model, which posit a $50^{\circ}$ clockwise rotation of the PSP with southward translation between 50 and $40 \mathrm{Ma}$, no significant movement between 40 and $25 \mathrm{Ma}$ and $40^{\circ}$ clockwise rotation between 25 and $0 \mathrm{Ma}$ for the southern part of the plate, and clockwise rotation and northward movement between 50 and $0 \mathrm{Ma}$ for the northeastern part. Despite large uncertainties in rotational motions, they were able, using that model, to account for tectonic interactions with the Huatung Basin along the eastern margin during the Eocene.

Seton et al. (2015), assuming that the Izanagi slab detachment beneath East Asia was responsible for major plate reorganization, have examined the consequences on mantle flow in the Pacific region between $\sim 53$ and 47 Ma. Their geodynamic calculations, compared with tomography data, let them argue that the flow changed from southward before $60 \mathrm{Ma}$ to north-northeastward after $50 \mathrm{Ma}$, corroborating the paleolatitudes given by paleomagnetic data (Hall et al. 1995c, Richter and Ali 2015).

\section{Cretaceous terranes origin}

Around $\sim 60-50 \mathrm{Ma}$, the proto-PSP was located in the southern hemisphere (Richter and Ali 2015). A wide Mesozoic oceanic basin, called the New Guinea ophiolite back-arc basin, separated the Australian continent from the proto-PSP (Hall 2002; Pubellier et al. 2003). Such a paleo-basin is a good candidate for the origin of Early Cretaceous Huatung Basin rocks with Indian MORB characteristics (Hickey-Vargas et al. 2008). A strip of that New-Guinea Basin was trapped along the complex transform boundary that separated the Indonesia Arc from the East Mindanao-Samar Arc (Fig. 5, Deschamps and Lallemand 2002). Similarly, the Daito ridges show strong petrological, chronological, and geochemical affinities with the southern Philippine ophiolites (Tani et al. 2015). These terranes probably result from the splitting of the same proto-Philippine island arc region at the early stages of WPB rifting under the influence of the Oki-Daito plume (Fig. 5).

\section{Plume-ridge interaction, boninites' and FABs' geodynamic setting}

A key point in discussing the early stages of the PSP and IBM subduction concerns the petrologic and geodynamic significance of the boninites, which were initially discovered on the Bonin Islands and then at several locations along the IBM fore-arc up to Palau Island. Boninitic magmatism represents a distinctive style of subduction-related magmatism, thought to result from melting strongly depleted mantle that is variably metasomatized by slabderived fluids or melts (Crawford et al. 1989; Pearce et al. 1992). Boninites are therefore a rare type of subductionrelated magma. They are much richer in $\mathrm{H}_{2} \mathrm{O}$, and require much more refractory sources than normal island arc suites. Their genesis requires a depleted mantle peridotite, a source of $(\mathrm{C}-\mathrm{O}-\mathrm{H})$ volatiles and an abnormally high geothermal gradient in relatively shallow levels of the mantle wedge.

Based on present-day fore-arc magma records, they are often referred to as suprasubduction-zone ophiolites. Several petrologists (Whattam and Stern 2011; Stern et al. 2012) claim that their eruption follows the "subduction initiation rule" in which the magma source changes progressively in composition due to the combined effects of melt depletion and subduction-related metasomatism. Magmas progress from early decompression melts of unmodified fertile mantle to yield "fore-arc" basalts to younger hydrous flux melts of depleted mantle that has been strongly 
modified by subduction-related fluids to yield late high-Mg andesites and boninitic lavas. Finally, normal arc volcanics (tholeiites) cap the subduction initiation sequence (Stern et al. 2012). Metcalf and Shervais (2008), Reagan et al. (2010) and Ishizuka et al. (2011b) described the genetic link in the magmatic suite constituting the "present-day fore-arc" ophiolites along the IBM subduction zone starting from the $\sim 50-52 \mathrm{Ma}$ so-called FABs, then the $44-$ $48 \mathrm{Ma}$ boninite andesites and their differentiates and/ or the $44-45 \mathrm{Ma}$, transitional high-Mg andesites, finally topped by the post $44 \mathrm{Ma}$ arc tholeiites and calc-alkaline rocks.

Macpherson and Hall (2001) observed that boninitic magmatism is not recognized in younger subduction zones of similar dimensions (Crawford et al. 1989) like, for example, the Hjort-Macquarie-McDougall-Puysegur incipient subduction (Meckel et al. 2005). Macpherson and Hall (2001) suggest an additional tectonic or thermal factor which could influence the generation of boninites and posit that a mantle plume influenced the magmatic and tectonic evolution of the western Pacific since the Middle Eocene. Occurrences of recent boninites are reported from the North Tonga Ridge (e.g., Falloon et al. 1989), the Valu Fa Ridge in the Lau Basin (Kamenetsky et al. 1997), and the southern New Hebrides arc (Monzier et al. 1993). Deschamps and Lallemand (2003) observed that the geodynamic setting was the same in each of these examples, i.e., eruptions occurred at the intersection between a back-arc spreading ridge and a volcanic arc. Moreover, based on their reconstruction of the WPB in 2002, they noted that the IBM boninites roughly coincided with the intersection between back-arc rifts or spreading centers and the proto-IBM arc. Such geodynamic context is exceptional because most of the time, the rift or back-arc spreading center parallels the arc. Specific conditions are needed to make spreading centers and arcs intersect. Among these is the influence of a mantle plume that disorganizes the mantle flow in the back-arc region.

It is highly probable that the FABs that underlie the boninites not only occur in the IBM fore-arc, but also constitute part of the basement of the short-lived backarc basins in the ADO region (Ishizuka et al. 2015; Arculus et al. 2015). The occurrence of both FABs and boninites in a modern fore-arc setting is the result of arc consumption by tectonic erosion after their early emplacement. These lavas were initially emplaced far from the incipient trench either in a rear-arc position like the Valu Fa lavas, or in a stretched arc at the termination of a rift like in northern Tonga or in the southern New Hebrides. In section 7 , we propose a scenario for the early stages of IBM subduction and associated magmatism that satisfies all previous constraints.

\section{Toward an integrative tectono-magmatic model of the IBM subduction zone}

Several paleoreconstructions of PSP evolution have been proposed (e.g., Uyeda and Ben Avraham 1972; Karig 1975; Seno and Maruyama 1984; Jolivet et al. 1989; Hall et al. 1995a; Lee and Lawver 1995; Hall 2002; Deschamps and Lallemand 2002; Pubellier et al. 2004; Honza and Fujioka 2004; Sdrolias and Müller 2006; Gaina and Müller 2007; Zahirovic et al. 2014; Seton et al. 2015). In this study, we do not pretend to provide a complete update of PSP tectonic evolution but rather highlight key phases, especially during the early stages of the evolution and IBM subduction initiation, and connect them into an integrated model of evolution that satisfies the existing geological, geochemical, geochronological and mechanical constraints.

\section{Proto-PSP environment}

The proto-PSP consisted of Mesozoic terranes of various origins including island arcs such as the Daito ridges and some Philippine ophiolitic complexes (Hall 2002; Hickey-Vargas et al. 2008; Tani et al. 2015). At the time of PSP inception (Fig. 5), there is no clear evidence whether the Huatung Basin, which probably originated from a larger Mesozoic back-arc basin north of Australia, was already trapped or not. If not, the docking of a strip of that basin through the jump of the plate boundary from the former Gagua fracture zone to another subparallel fracture/transform fault occurred soon because the trapped piece of Huatung crust moved northward with the PSP from the very beginning (Deschamps and Lallemand 2002). The simplest configuration that can be derived from the above observations is that the Mesozoic terranes ( 60 m.y. fossil arcs at that time) lay behind the active proto-Philippine Arc. These fossil arc terranes were separated from the Pacific oceanic plate by a transform fault that allowed the Izanagi and Pacific plates to subduct beneath East Asia (e.g., Seton et al. 2015).

\section{Consequences of Izanagi slab detachment}

At the end of the Paleocene ( 60-55 Ma), the whole of East Asia underwent the subduction of the IzanagiPacific active spreading ridge (Whittaker et al. 2007; Zahirovic et al. 2014). Since the ridge segments were subparallel to the former margin, the Izanagi plate detached as a whole, resulting in a drastic change in mantle flow dynamics across the whole West Pacific and East Asia (Seton et al. 2015). This major tectonic event modified not only the driving forces of the Pacific plate and thus the plate motion direction, but also those of the surrounding plates through a change in mantle flow. In such a context, convergence might have localized along the weak fracture zone separating the Pacific plate 
from the proto-PSP, which was composed of Mesozoic terranes. Oblique shortening might have started as early as 60-55 Ma ago, then thrusting localized and subduction of the Pacific plate started. The cumulative downwelling action of the former proto-Philippine northeastward-vergent subduction and the mantle flow reorganization following the Izanagi slab detachment may have triggered localized mantle upwelling, further called the "Oki-Daito mantle plume" around 50-52 Ma (Fig. 5).

\section{Impact of the Oki-Daito plume}

As in the North Fiji Basin, the proto-PSP split into several "terranes" under the plume's influence (HickeyVargas et al. 2008; Faccenna et al. 2010). Multiple spreading centers with various orientations ruptured the newly formed PSP, especially during the earlier stages at $\sim 52-45 \mathrm{Ma}$. Some of them, especially in the ADO region, gave rise to short-lived oceanic basins like the Kita-Daito, Amami-Sankaku or Minami-Daito basin or the piece of the WPB north of the ODE. The plume thus likely triggered basins opening as attested by the presence of OIB dikes and sills in the Minami-Daito Basin. The fact that the FAB-like lavas drilled in the Amami-Sankaku Basin do not exhibit a plume-like geochemical signature may indicate that the spreading centers propagated outside of the plume's area of influence. Plateaus, formed by excess magma, or seamounts with OIB signatures, developed essentially in the northern part of the present WPB, including the MinamiDaito Basin ( 43-51 Ma), Oki-Daito Ridge ( 48 Ma), Oki-Daito Rise ( 40-45 Ma), Urdaneta Plateau ( 40$36 \mathrm{Ma}$ ) and Benham Rise ( $\sim 36 \mathrm{Ma})$ (Ishizuka et al. 2013). Typical failed rifts and propagators characterize the region between the Urdaneta Plateau and the Benham Rise (Figs. 1, 2, 3, and 5, Deschamps et al. 2008).

\section{IBM subduction inception}

The IBM subduction zone initiated in the region of the former transform boundary between the splitting Mesozoic terranes that were essentially composed of former island arcs and the Pacific plate. Since the oldest lavas that include subduction components (near the KPRDaito Ridge intersection) are 48-49 Ma old (Ishizuka et al. 2011a), we suppose that about 10 m.y. were necessary for the former transform boundary to turn into a subduction, as suggested by numerical models (Leng and Gurnis 2011; Leng et al. 2012). At this stage, it is important to note that subduction did not initiate along a transform fault separating a younger and an older oceanic plate as has often been described (e.g., Shervais and Choi 2011; Stern et al. 2012) but along a transform boundary between Mesozoic terranes characterized by a crust $\sim 20 \mathrm{~km}$ thick (Nishizawa et al. 2014) and an oceanic plate characterized by a 6-7 km crust but with a lithosphere of highly variable thickness along the strike. Indeed, reconstructions by Zahirovic et al. (2014) and Seton et al. (2015) indicate that the age of the Pacific plate varies from $\sim 0$ in the north to $\sim 80 \mathrm{Ma}$ in the south of the proto-IBM arc. Sdrolias and Müller (2006) proposed a more restricted age range between 30 and $70 \mathrm{Ma}$. In any case, it is quite clear that the oceanic crust (Pacific Plate), whatever its age, will tend to subduct beneath the Mesozoic terranes that are more buoyant if the region undergoes compression. To be complete, we must admit that young oceanic basins formed during subduction initiation, so the proto-PSP ended up consisting of alternating thick Mesozoic arc terranes and newly formed oceanic crust, as also noticed by Leng and Gurnis (2015).

The mode of failure along that transform boundary is unknown, but we can learn from similar known or recent geodynamic contexts. The Australia-Pacific plate boundary south of New Zealand offers an excellent ana$\log$ to the proto-IBM situation because its former purely transform boundary evolved into a series of incipient subductions from Puysegur in the north to Hjort in the south. At the latitude of the Puysegur Trench, the young Tasman oceanic basin ( 10 Ma) began to subduct beneath the Campbell Plateau and Solander Trough in the Miocene (Lebrun et al. 2003). Detailed investigations have shown that the former transform fault is still active in the upper part of the Puysegur Ridge. Failure occurred on the Tasman side at a distance from the transform fault along a shallow-dipping thrust, so that the trench is now located at $\sim 20-50 \mathrm{~km}$ from the fault (Collot et al. 1995). Similar observations can be done in the Hjort sector with the young Southwest Tasman Basin ( 5-9 Ma) subducting beneath the Macquarie Ridge Complex, which includes the Hjort Plateau, since 6-11 Ma (Meckel et al. 2003). Inspired by these recent examples and by mechanical considerations (e.g., Shemenda 1992), we suggest that the initial thrusting occurred within the Pacific plate at a distance of a few tens of kilometers from the former transform boundary. The former transform fault probably remained active, partitioning the strain if we assume that the convergence was oblique for a long time after subduction initiated. Such geometry favors the lateral migration of a fore-arc sliver (McCaffrey 1992; Lallemand et al. 1999). In the proto-IBM case, the fore-arc sliver was likely composed of Pacific oceanic lithosphere (an ophiolitic wedge of Pacific origin). Considering that the trench-transform distance likely depends on respective lithosphere thicknesses, it may vary along-strike depending on the plate's age. Since kinematic reconstructions, in Seton et al. (2015), for example, indicate that the age of the Pacific plate increases southward from 0 to $80 \mathrm{Ma}$, we can reasonably assume 
that the Pacific fore-arc sliver will be wider in the south (Fig. 5).

At this stage, it is important to note the difference between spontaneous and forced subduction initiation in a geodynamic context that bears magmatic sources in mind. Indeed, most petrologists (Stern and Bloomer 1992; Shervais and Choi 2011; Stern et al. 2012; Ishizuka et al. 2014) consider that the asthenospheric mantle invades the gap between "sinking old" and "young buoyant" lithospheres, inducing during fore-arc spreading (FABs and boninites), but since spontaneous subduction is unlikely and "compression is the rule" (Hall et al. 2003), there is no available space for the mantle to reach the fore-arc region. Consequently, the first lavas erupted at a significant distance from the incipient trench.

\section{Tectono-magmatic model of PSP inception, IBM subduction initiation and evolution}

Chronologically, we propose the following tectonomagmatic events flow at the scale of the whole IBM system (Figs. 5 and 6):

60-55 Ma: Izanagi slab detachment beneath the East Asia margin triggers diffuse shortening across the region accommodating the transform motion between the Mesozoic composite proto-PSP and the Pacific oceanic plate.

55-52 Ma: mantle flow reorganization after slab detachment and interaction with local mantle convection (proto-Philippine subduction) contributed to the formation of the Oki-Daito plume. 54-48 Ma: multiple rifts developed under the influence of the plume, splitting the composite protoPSP into several ridges separated by short-lived oceanic basins. Those at the head of the plume were intruded by OIB sills like the Minami-Daito Basin but others still show Indian-ocean MORB signatures in their $\mathrm{Pb}$ isotopic composition (Ishizuka et al. 2011b; Ishizuka et al. 2013; Hickey-Vargas et al. 2013). The FABs described in the Bonin and Mariana fore-arcs belong to this group. These oceanic basins opened back of the transform fault, probably without or with little contamination from the down-going Pacific plate. One of the spreading centers, subparallel to the proto-Philippine Arc, gave rise to the oldest crust of the WPB. This was abandoned after a few m.y. through a ridge jump. 52-48 Ma: after several m.y. of diffuse shortening across the transform boundary region, the deformation localized along a thrust fault cutting through the Pacific plate, incorporating a Pacific ophiolite into the newly formed PSP. Behind the transform fault, the PSP lithosphere stretched, creating an alternance of thick island arc remnants and thin oceanic lithosphere (FABs). The width of the Pacific fore-arc sliver was probably larger in the south where the subducting plate was older. The subducting Pacific plate probably deformed, with undulations, because the thickness of the overriding lithosphere varied along-strike from the Mesozoic ridges to the young, thin oceanic lithosphere. The subducting Pacific crust thus reached the mantle corner sooner beneath the newly formed basins than beneath the ridges.

49-34 Ma: the first boninites are supposed to have erupted around $\sim 49-48 \mathrm{Ma}$, persisting for about 15 m.y (Cosca et al. 1998). Following the geodynamic setting proposed by Deschamps and Lallemand (2003), we believe that these lavas did not erupt in a fore-arc position, but rather in an incipient arc and/or rear-arc position mostly at the intersection between the spreading centers of the young oceanic basins and the juvenile arc. These are considered to be the first "arc-related lavas" because they are stratigraphically at the bottom of the volcanic suite, but they were still erupting 15 m.y. after subduction initiation. This clearly indicates, if necessary, that the conditions for their eruption include a specific geodynamic context including an arcridge intersection as in the Valu Fa Arc (Tonga), rather than fitting the beginning of subduction.

$<45 \mathrm{Ma}$ : high-Ca boninites and high-Mg andesites sometimes appear atop low-Ca boninites on some Bonin or Mariana islands (Ishizuka et al. 2006). They mark the transition between highly depleted mantle sources and the high degrees of fluxed melting at shallow levels that generated boninites and normal arc volcanism (Reagan et al. 2008). Then, typical arc tholeiites and calc-alkaline rocks formed, contributing to the growth of the IBM Arc. The delay of a few m.y. between the oldest boninites and the oldest arc tholeiites is simply explained by the time needed for the Pacific crust to reach the mantle wedge beneath the Mesozoic ridges and the thickening lithosphere associated with the FABs.

$<40$ ? Ma: tectonic erosion of the frontal margin has been documented during the Neogene and possibly as soon as the Middle Eocene (Lallemand 1995). It has been accompanied by fore-arc subsidence/consumption and volcanic front retreat (Fig. 7). At least $150 \mathrm{~km}$ of frontal margin has been subducted and partly recycled into arc magmatism (Bloomer 1983; Lallemand 1996, 1998). This erosional process permitted the oldest FABs, arc boninites, and tholeiites to outcrop today near the trench. Most or all of the Pacific ophiolite has probably been lost into the subduction zone. Discoveries of Mesozoic cherts and ophiolitic suites in some rare places may represent remnants of the Pacific relics trapped during subduction initiation as well as pieces of seamounts offscrapped from the down-going plate later (Johnson et al. 1991). The widespread serpentinite mud 


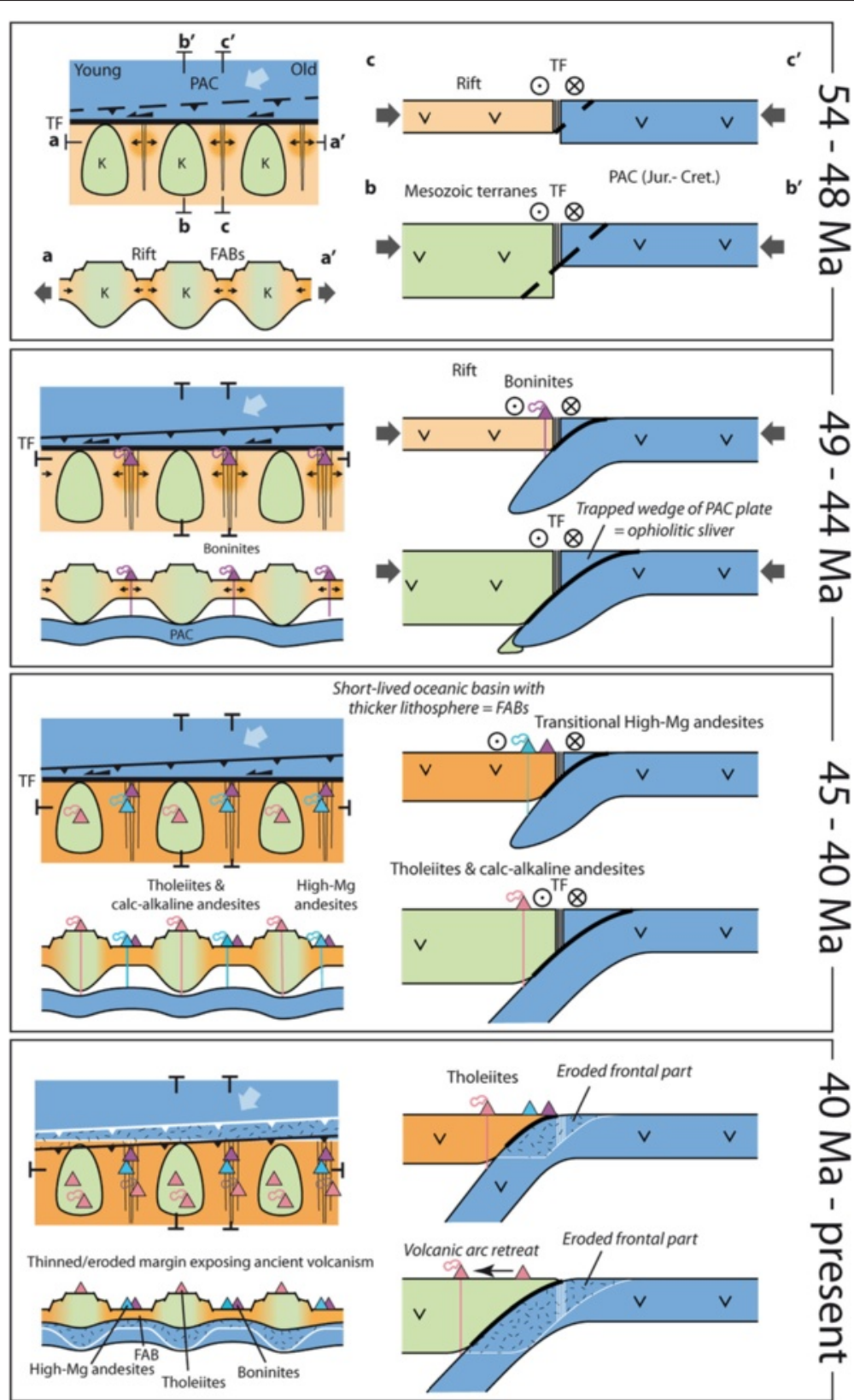

Fig. 6 Schematic tectono-magmatic model of IBM subduction initiation and early evolution. Special emphasis has been done on the geodynamic context of various magma eruptions. The white lines in stage "40 Ma - present" represent the former positions of plate boundaries or the base of the upper plate in stage "45-40 Ma". TF = transform fault, PAC = Pacific, FAB = Fore-arc basalts

volcanoes observed in the Mariana fore-arc (Fryer et al. $1985,1999)$ are very interesting because they are the only ones known to be active in this context today. Fluids from the descending plate hydrate the fore-arc mantle and enable serpentinite muds to rise along faults to the seafloor (Fryer 2012). Blueschists found in the mud attest that they originate from depths as great as $25 \mathrm{~km}$ and their ascent is probably facilitated by subvertical faults cutting through the fore-arc (Fryer et al. 2006). Following our scenario, we propose that they form along the segments of the initial paleo-transform fault zone that have been preserved from erosion. As suggested above, the Pacific sliver should have been wider in the Mariana fore-arc because it was thought to be much older than in the Izu-Bonin fore-arc. Logically, for a constant amount of tectonic erosion along the IBM fore-arc, the southern part is more likely to preserve Pacific remnants than the northern part. Such a paleo-transform is a good candidate for both a subvertical faulted zone and hydration, and thus 

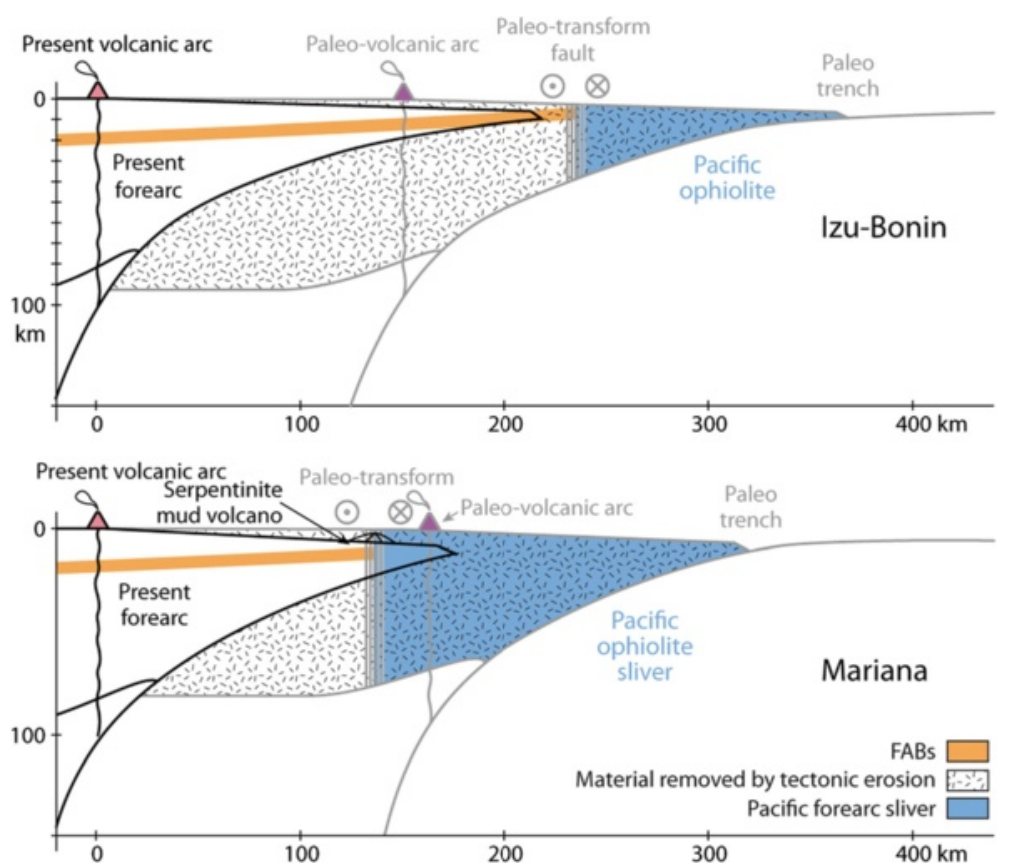

Fig. 7 Schematic cross-sections of Izu-Bonin and Mariana fore-arcs at early stage and at present. This cartoon emphasizes the differences in structural settings that might favor the rise of serpentinite mud diapirs. FABs fore-arc basalts. As in Fig. 4, black and grey lines outline the present and reconstructed slab's top and upper plate geometries with respect to a reference line that could be the present volcanic arc

serpentinite formation. If this hypothesis is correct, we should find remnants of the former Pacific ophiolite trenchward of that zone. The discoveries of Johnson et al. (1991) in the Mariana fore-arc could represent a first sign that this is the case.

\section{Conclusions}

Compiling all the data available on the composite PSP, we were able to depict the earlier stages of PSP evolution within a coherent integrative approach.

Based on our calculations, the total PSP area can be roughly estimated to cover $\sim 8.710^{6} \mathrm{~km}^{2}$, with about $2 / 3$ $\left(\sim 5.910^{6} \mathrm{~km}^{2}\right)$ constituting the present-day visible part of the PSP, one fourth $\left(\sim 2.210^{6} \mathrm{~km}^{2}\right)$ is already subducted beneath the Ryukyu and Philippine arcs, and the remaining $0.610^{6} \mathrm{~km}^{2}$ has been eroded along its eastern boundary.

Based on the timing of events, the most likely trigger of PSP inception is the Izanagi slab detachment beneath the East Asia margin. Such a mega-event has been dated 60-55 Ma, which gave enough time for the paleotransform boundary between the Pacific plate and the proto-PSP to localize the deformation, evolve into a subduction zone around 52-50 $\mathrm{Ma}$ and produce the first boninitic lavas a few m.y. later around 49-48 Ma. At the same time, mantle flow reorganization triggered the formation of the Oki-Daito plume, which triggered, or enhanced, the splitting of the composite Mesozoic proto-PSP into several pieces around 54-50 Ma. The plume also controlled the formation of the long-lived WPB behind the proto-Philippine Arc, especially in its northern sector, during the first 15 m.y. of opening. The IBM trench developed within the Pacific Plate, likely isolating a fore-arc sliver composed of a Pacific ophiolite bounded arcward by a paleo-transform zone. Later, tectonic erosion of the fore-arc removed most of the Pacific fore-arc material, except in a few areas, like off the Mariana Arc, where some remnants may outcrop, as well as serpentinite diapirs that might have developed along the altered paleo-transform relics. The ophiolitic suite presently sampled in the IBM fore-arc was not formed in a fore-arc position but at a significant distance $(>50 \mathrm{~km})$ from the incipient trench, which would account for the considerable amount of material consumed at the front of that margin. Consequently, FABs and fortiori boninites are not markers s.s. of subduction initiation. The so-called "fore-arc basalts" were formed along shortlived spreading ridges, far and out of the influence of the Pacific subduction, until the slab's crust reached the depth of dehydration, favoring the eruption of the boninites. The intersection of numerous spreading centers and the newly forming arc above a shallow slab satisfied the necessary conditions for boninite formation. Use of the word "fore-arc" to characterize these basalts and boninites is genetically not appropriate.

Further investigations and physical experiments are needed to validate our model. 


\section{Abbreviations}

ADO: Amami-Daito-Oki-Daito; CBF: Central Basin Fault; DSDP: Deep-Sea Drilling Project; FABs: fore-arc basalts; FZ: fracture zone; IBM: Izu-BoninMariana; IODP: International Ocean Discovery Program; IP: Izanagi-Pacific; KPR: Kyushu-Palau Ridge; LOFZ: Luzon-Okinawa fracture zone; MORBs: midocean ridge basalts; NTD: non-transform discontinuity; ODE: Oki-Daito Escarpment; OIB: ocean island basalt; PSP: Philippine Sea Plate; WPB: West Philippine Basin.

\section{Competing interests}

The author declares that he has no competing interests.

\section{Authors' information}

The author, after spending the first 2 years of his PhD studies at the Ocean Research Institute - Tokyo University in the early 1980s, has focused most of his research studies on understanding subduction processes, with special emphasis on the Japan and Taiwan areas. He collaborated with Anne Deschamps during her Master's and PhD studies as well as during her post-doctoral research at JAMSTEC between 1997 and 2003. Significant results on the geodynamics of the Philippine Sea Plate arose from that intense collaborative period. Anne should have co-authored this review paper if she had still been alive.

\section{Acknowledgements}

I dedicate this review to Anne Deschamps who left us recently and who has provided crucial constraints on the Gagua Ridge, the Huatung Basin, the Mariana Trough and the Izu-Bonin-Mariana arc. Her major contribution, however, concerns the tectonic evolution of the West Philippine Basin. In memory of her new insights, especially on the "Central Basin Fault rift," Yasuhiko Ohara and Toshiya Fujiwara have suggested naming an oceanic high fringing the CBF rift in the center of the Philippine Sea Plate the "Deschamps seamount." Their suggestion was approved unanimously by the Intergovernmental Oceanographic Commission of UNESCO in mid-October 2015. This paper's cover image shows a detailed map of the Deschamps seamount (Ohara et al. 2015) and a picture of Anne Deschamps taken in 2010 before she explored the East Pacific Rise using the 6000 m deep-sea submersible Nautile. Thanks to Jean-Yves Royer who provided me with this photograph.

I wish to express my deep thanks to the convenors of the special session on "Tectonic evolution of Northeast Asia" at the Japan Geoscience Union Meeting hold in Makuhari in May 2015, Jonny Wu, Kyoko Okino, Gaku Kimura, and Cedric Legendre. I also sincerely thank the Japan Geoscience Union for providing me support for my visit. Anne Delplanque efficiently redrew my sketches and Stéphane Dominguez kindly provided the bathymetric charts for the cover image and Figs. 1 and 2. Part of this review was inspired by the scientific exchanges that I had during the JpGU Meeting with Gaku Kimura, Ken Tani, Ryuichi Shinjo, and Osamu Ishizuka. I was also inspired by the numerous discussions in the laboratory with Diane Arcay, Sarah Abecassis, Marguerite Godard, and Fleurice Parat, but the main substance of the review paper matured from the joint work done with Anne Deschamps.

\section{Received: 18 November 2015 Accepted: 4 April 2016}

\section{Published online: 12 May 2016}

\section{References}

Angelier J (1986) Preface. In: Geodynamics of the Eurasia-Philippine Sea plate boundary. Tectonophysics, vol 125., pp IX-X

Aoike K (2001) Geology of the Tanzawa, Misaka and Koma districts, central Japantectonic evolution of the Izu collision zone. Dissertation, University of Tokyo

Arai R, Iwasaki T, Sato H, Abe S, Hirata N (2009) Collision and subduction structure of the Izu-Bonin arc, central Japan, revealed by refraction/wideangle reflection analysis. Tectonophysics 475:438-453

Arculus RJ, Ishizuka O, Bogus KA, Gurnis M, Hickey Vargas R, Aljahdali MH, Bandini Maeder AN, Barth AP, Brandl PA, Drab L, Do Monte Guerra R, Hamada M, Jiang F, Kanayama K, Kender S, Kusano Y, Li H, Loudin LC, Maffione M, Marsaglia KM, McCarthy A, Meffre S, Morris A, Neuhaus M, Savov IP, Sena C, Tepley FJ III, Van Der Land C, Yogodzinski GM, Zhang A (2015) A record of spontaneous subduction initiation in the Izu-Bonin-Mariana arc. Nat Geosci 8:728-733. doi:10.1038/NGEO2515
Asada M, Deschamps A, Fujiwara T, Nakamura Y (2007) Submarine lava flow emplacement and faulting in the axial valley of two morphologically distinct spreading segments of the Mariana back-arc basin from Wadatsumi side-scan sonar images. Geochem Geophys Geosyst 8:4. doi:10.1029/2006GC001418

Azema J, Blanchet R et al (1981) The Late Jurassic-Early Cretaceous Genus Calpionella in reworked pebbles from Deep Sea Drilling Project Site 460, Mariana transect. In: Hussong DM, Uyeda S (eds) Initial reports of the Deep Sea Drilling Project 60. US Government Printing Office, Washington DC, pp 574-575

Baker N, Fryer P, Martinez F, Yamazaki T (1996) Rifting history of the northern Mariana Trough: seaMARC II and seismic reflection surveys. J Geophys Res 101:11427-11455

Bijwaard H, Spakman W, Engdahl R (1998) Closing the gap between regional and global travel time tomography. J Geophys Res 103:30055-30078

Bloomer SH (1983) Distribution and origin of igneous rocks from the landward slopes of the Mariana Trench: Implications for its structure and evolution. J Geophys Res 88:7411-7428

Cao L, Wang Z, Wu S, Gao X (2014) A new model of slab tear of the subducting Philippine Sea Plate associated with Kyushu-Palau Ridge subduction. Tectonophysics 636:158-169. doi:10.1016/j.tecto.2014.08.012

Cardwell RK, Isacks BL, Karig DE (1980) The spatial distribution of earthquakes, focal mechanisms solutions, and subducted lithosphere in the Philippine and northeastern Indonesian Islands. In: Hayes DE (ed) The tectonic and geologic evolution of southeast Asian seas and islands, part 1, geophys monogr Ser 23. AGU, Washington DC, pp 1-35

Chamot-Rooke N, Renard V, Le Pichon X (1987) Magnetic anomalies in the Shikoku basin: a new interpretation. Earth Planet Sci Lett 83:214-228

Collot J-Y, Lamarche G, Wood RA, Delteil J, Sosson M, Lebrun J-F, Coffin MF (1995) Morphostructure of an incipient subduction zone along a transform plate boundary: Puysegur ridge and trench. Geology 23:519-522

Cosca MA, Arculus RJ, Pearce JA, Mitchell JG (1998) ${ }^{40} \mathrm{Ar} /{ }^{39} \mathrm{Ar}$ and K-Ar geochronological age constraints for the inception and early evolution of the Izu-Bonin- Mariana arc system. Isl Arc 7:579-595. doi:10.1111/j.1440-1738. 1998.00211.x

Crawford AJ, Falloon TJ, Green DH (1989) Classification, petrogenesis and tectonic setting of boninites. In: Crawford AJ (ed) Boninites and related rocks. Unwin Hyman, London, pp 1-49

DeMets C, Gordon RG, Argus DF (2010) Geologically current plate motions. Geophys J Int 181:1-80

Deschamps A, Lallemand S, Collot JY (1998) A detailed study of the Gagua Ridge: a fracture zone uplifted during a plate reorganization in the Mid-Eocene. Mar Geophys Res 20(5):403-423

Deschamps A, Lallemand S, Dominguez S (1999) The last spreading episode of the West Philippine Basin revisited. Geophys Res Lett 26(14):2073-2076

Deschamps A, Monié P, Lallemand S, Hsu S-K, Yeh J (2000) Evidence for Early Cretaceous oceanic crust trapped in the Philippine Sea Plate. Earth Planet Sci Lett 179(3-4):503-516

Deschamps A, Lallemand S (2002) The West Philippine Basin: a PaleoceneOligocene backarc basin opened between two opposed subduction zones. J Geophys Res 107(12):2322. doi:10.1029/2001JB001706

Deschamps A, Okino K, Fujioka K (2002) Late amagmatic extension along the central and eastern segments of the West Philippine Basin fossil spreading axis. Earth Planet Sci Lett 203:277-293

Deschamps A, Fujiwara T (2003) Asymmetric accretion along the slow spreading Mariana Ridge. Geochem Geophys Geosyst 4(10):8622. doi:10.1029/2003GC000537

Deschamps A, Lallemand S (2003) Geodynamic setting of Izu-Bonin-Mariana boninites. In: Larter RD, Leat PT (eds) Intra-oceanic subduction systems: tectonic and magmatic processes, Geol Soc, vol 219. Spe Publ, London, pp 163-185

Deschamps A, Fujiwara T, Asada M, Montési L, Gente P (2005) Faulting and volcanism in the axial valley of the slow spreading center of the Mariana back-arc basin from Wadatsumi side-scan sonar images. Geochem Geophys Geosyst 6:1. doi:10.1029/2004GC000881

Deschamps A, Shinjo R, Matsumoto T, Lee CC, Lallemand S, Wu S (2008) Sci. party of KR03-04 and KR04-14 cruises (2008) Propagators and ridge jumps in a back-arc basin, the West Philippine Basin. Terra Nova 20:327-332. doi:10.111/j.1365-3121.2008.00824.x

Dominguez S, Lallemand SE, Malavieille J, von Huene R (1998) Upper plate deformation associated with seamount subduction. Tectonophysics 293:207-224 
Doo WB, Hsu SK, Yeh YC, Tsai CH, Chang CM (2015) Age and tectonic evolution of the northwest corner of the West Philippine Basin. Mar Geophys Res 36: 113-125. doi:10.1007/s11001-014-9234-8

Eakin DH, McIntosh KD, Van Avendonk HJA, Lavier L (2015) New geophysical constraints on a failed subduction initiation: The structure and potential evolution of the Gagua Ridge and Huatung Basin. Geochem Geophys Geosyst 16:1-21. doi:10.1002/2014GC005548

Expedition 351 Scientists (2015) Izu-Bonin-Mariana arc origins: continental crust formation at an intra-oceanic arc: foundation, inception, and early evolution. International Ocean Discovery Program Preliminary Report, 351. doi.org/10.14379/iodp.pr.351.2015

Faccenna C, Heuret A, Funiciello F, Lallemand S, Becker T (2007) Predicting trench and plate motion from the dynamics of a strong slab. Earth Planet Sci Lett 257:29-36

Faccenna C, Becker TW, Lallemand S, Lagabrielle Y, Funiciello F, Piromallo C (2010) Subduction-triggered magmatic pulses: a new class of plumes? Earth Planet Sci Lett 299:54-68. doi:10.1016/j.epsl.2010.08.012

Faccenna C, Becker TW, Lallemand S, Steinberger B (2012) On the role of slab pull in the Cenozoic motion of the Pacific plate. Geophys Res Lett 39:L03305. doi:10.1029/2011GL050155

Falloon TJ, Green DH, McCulloch MT (1989) Petrogenesis of high-Mg and associated lavas from the North Tonga Trench. In: Crawford AJ (ed) Boninites and related rocks. Unwin Hyman, London, pp 357-395

Forsyth D, Uyeda S (1975) On the relative importance of the driving forces of plate motion. Geophys J R Astron Soc 43:163-200

Fryer P, Smoot NC (1985) Processes of seamount subduction in the Mariana and Izu-Bonin trenches. Mar Geol 64:77-90

Fryer P, Ambos EL, Hussong DM (1985) Origin and emplacement of Mariana forearc seamounts. Geology 13:774-777

Fryer P (1992) A synthesis of Leg 125 drilling of serpentine seamounts on the Mariana and Izu-Bonin forearcs. Proc Ocean Drill Program Sci Results 125:593-614

Fryer P, Pearce JA, Stokking LB, Ali JR, Arculus R, Ballotti D, Burke M, Ciampo G, Haggerty JA, Haston RB, Heling D, Hobart MA, Ishii T, Johnson LE, Lagabrielle Y, McCoy FW, Maekawa H, Marlow MS, Milner G, Mottl MJ, Murton BJ, Phipps SP, Rigsby CA, Saboda KL, Stabell B, van der Laan S, Wu Y (1992) Proc ODP, Sci. Results. ODP: Ocean Drilling Program, Leg 125: College Station, TX

Fryer P (1995) Geology of the Mariana Trough. In: Taylor B (ed) Backarc basins: tectonics and magmatism. Plenum Press, New York, NY, pp 237-279

Fryer P, Wheat CG, Mottl MJ (1999) Mariana blueschist mud volcanism: implications for conditions within the subduction zone. Geology 27:103-106

Fryer P, Gharib J, Ross K, Savov I, Mottl MJ (2006) Variability in serpentinite mudflow mechanisms and sources: ODP drilling results on Mariana forearc seamounts. Geochem Geophys Geosyst 7:8. doi:10.1029/2005GC001201

Fryer P (2012) Serpentinite mud volcanism: observations, processes and implications. Annu Rev Mar Sci 4:345-373. doi:10.1146/annurev-marine-120710-100922

Fujioka K, Kobayashi K, Fujiwara T, Kitazato H, Iwabuchi Y, Tamura C, Omori K, Kato K, Ariyoshi M, Kodera T (1996) Tectonics of the southern tip of the Philippine Sea-Results of Southerncross'95 cruise-JAMSTEC. J Deep Sea Res 12:275-290

Fujioka K, Okino K, Kanamatsu T, Ohara Y, Ishisuka O, Haraguchi S, Ishii T (1999) Enigmatic extinct spreading center in the West Philippine backarc basin unveiled. Geology 27:1135-1138

Fujiwara T, Tamaki K, Fujimoto H, Ishii T, Seama N, Toh H, Koizumi K, Igarashi C, Segawa J, Kobayashi K (1995) Morphological studies of the Ayu Trough, Philippine Sea-Caroline Plate boundary. Geophys Res Lett 22(2):109-112

Fujiwara T, Tamura C, Nishizawa A, Fujioka K, Kobayashi K, Iwabuchi Y (2000) Morphology and tectonics of the Yap Trench. Mar Geophys Res 21:69-86

Gaina C, Müller D (2007) Cenozoic tectonic and depth/age evolution of the Indonesian gateway and associated back-arc basins. Earth Sci Rev 83:177-203. doi:10.1016/j.earscirev.2007.04.004

Gardner JV (2010) The west Mariana ridge, western Pacific Ocean: geomorphology and processes from new multibeam data. GSA Bull 122(9/10):1378-1388. doi:10.1130/B30149.1

Gerya TV, Connolly JAD, Yuen DA (2008) Why is terrestrial subduction one-sided? Geology 36:43-46

Gerya TV (2012) Intra-oceanic subduction zones. In: Brown D, Ryan PD (eds) Arc-continent collision, frontiers in earth sciences. Springer, Berlin Heidelberg. doi:10.1007/978-3-540-88558-0_2

Gerya TV, Stern RJ, Baes M, Sobolev SV, Whattam SA (2015) Plate tectonics on the Earth triggered by plume-induced subduction initiation. Nature 527:221-225. doi:10.1038/nature15752
Gurnis M, Hall C, Lavier L (2004) Evolving force balance during incipient subduction. Geochem Geophys Geosyst 5:Q07001. doi:10.1029/ 2003GC000681

Gutscher M-A, Lallemand S (1999) Birth of a major strike-slip fault in SW Japan. Terra Nova 11:203-209

Hall R (1987) Plate boundary evolution in the Halmahera region, Indonesia. Tectonophysics 144:337-352

Hall R, Fuller M, Ali JR, Anderson CD (1995a) The Philippine Sea Plate: magnetism and reconstructions. In: Taylor B, Natland J (eds) Active margins and marginal basins of the western pacific, geophys. Monogr. Ser., vol 88. AGU, Washington DC, pp 371-404

Hall R, Ali JR, Anderson CD, Baker SJ (1995b) Origin and motion history of the Philippine Sea Plate. Tectonophysics 251:229-250

Hall R, Ali JR, Anderson CD (1995c) Cenozoic motion of the Philippine Sea Plate: paleomagnetic evidence from eastern Indonesia. Tectonics 14:1117-1132

Hall R (1997) Cenozoic plate tectonic reconstructions of SE Asia. In: Fraser AJ, Matthews SJ, Murphy RW (eds.) Petroleum Geology of Southeast Asia. Geol Soc London Spec Publ 126, London, pp 11-23

Hall R (2002) Cenozoic geological and plate tectonic evolution of SE Asia and the SW Pacific: computer-based reconstructions, model and animations. J Asian Earth Sci 20:353-431

Hall CE, Gurnis M, Sdrolias M, Lavier LL, Müller RD (2003) Catastrophic initiation of subduction following forced convergence across fracture zones. Earth Planet Sci Lett 212:15-30. doi:10.1016/S0012-821X(03)00242-5

Hall R, Spakman W (2015) Mantle structure and tectonic history of SE Asia. Tectonophysics, in press. doi.org/10.1016/j.tecto.2015.07.003

Hawkins J, Batiza R (1977) Metamorphic rocks of the Yap arc-trench system. Earth Planet Sci Lett 37:216-229

Hickey-Vargas R (1991) Isotope characteristics of submarine lavas from the Philippine Sea: implications for the origin of arc and basin magmas of the Philippine tectonic plate. Earth Planet Sci Lett 107:290-304

Hickey-Vargas R (1998) Origin of the Indian Ocean-type isotopic signature in basalts from Philippine Sea plate spreading centers: an assessment of local versus large-scale processes. J Geophys Res 103:20963-20979

Hickey-Vargas R (2005) Basalt and tonalite from the Amami Plateau, northern West Philippine Basin: new Early Cretaceous ages and geochemical results, and their petrologic and tectonic implications. Isl Arc 14:653-665

Hickey-Vargas R, Bizimis M, Deschamps A (2008) Onset of the Indian Ocean isotopic signature in the Philippine Sea Plate: $\mathrm{Hf}$ and $\mathrm{Pb}$ isotope evidence from Early Cretaceous terranes. Earth Planet Sci Lett 268:255-267. doi:10.1016/j.epsl.2008.01.003

Hickey-Vargas R, Ishizuka O, Bizimis M (2013) Age and geochemistry of volcanic clasts from DSDP Site 445, Daito Ridge and relationship to Minami-Daito Basin and early Izu-Bonin arc magmatism. J Asian Earth Sci 70-71:193-208. doi:10.1016/j.jseaes.2013.03.013

Hilde TWC, Lee C-S (1984) Origin and evolution of the west Philippine Basin: a new interpretation. Tectonophysics 102:85-104

Honza E, Fujioka K (2004) Formation of arcs and backarc basins inferred from the tectonic evolution of Southeast Asia since the Late Cretaceous. Tectonophysics 384:23-53. doi:10.1016/j.tecto.2004.02.006

Hsu SK, Yeh YC, Sibuet JC, Doo WB, Tsai CH (2013) A mega splay fault system and tsunami hazard in the southern Ryukyu subduction zone. Earth Planet Sci Lett 362:99-107. doi:10.1016/j.epsl.2012.11.053

Huang Z, Zhao D, Hasegawa A, Umino N, Park JH, Kang IB (2013) Aseismic deep subduction of the Philippine Sea Plate and slab window. J Asian Earth Sci 75:83-94

Hussong DM, Uyeda S (1981) Tectonic processes and the history of the Mariana Arc: a synthesis of the results of Deep Sea Drilling Project Leg 60. Initial Rep Deep Sea Drill Proj 60:909-929

Ingle JC Jr, Karig DE, Bouma AH, Ellis H, Haile N, Koizumi I, Ling HY, MacGregor I, Moore JC, Ujiie H, Watanabe T, White SM, Yasui M (1975) Site 290. DSDP Initial Reports. doi:10.2973/dsdp.proc.31.102.1975

Ishizuka O, Kimura J-I, Li YB, Stern RJ, Reagan MK, Taylor RN, Ohara Y, Bloomer SH, Ishii T, Hargrove US III, Haraguchi S (2006) Early stages in the evolution of Izu-Bonin Arc volcanism: New age, chemical, and isotopic constraints. Earth Planet Sci Lett 250:385-401. doi:10.1016/j.epsl.2006.08.007

Ishizuka O, Yuasa M, Sakamoto I, Kanayama K, Taylor RN, Umino S, Tani K, Ohara $Y$ (2008) Earliest Izu-Bonin arc volcanism found on the submarine Bonin Ridge. Eos Trans AGU, 89(53), Fall Meet. Suppl., Abstract V31A-2106

Ishizuka O, Taylor RN, Yuasa M, Ohara Y (2011a) Making and breaking an island arc: a new perspective from the Oligocene Kyushu-Palau arc, Philippine Sea. Geochem Geophys Geosyst 12:5. doi:10.1029/2010GC003440 
Ishizuka O, Tani K, Reagan MK, Kanayama K, Umino S, Harigane Y, Sakamoto I, Miyajima Y, Yuasa M, Dunkley DJ (2011b) The timescales of subduction initiation and subsequent evolution of an oceanic island arc. Earth Planet Sci Lett 306:229-240. doi:10.1016/j.epsl.2011.04.006

Ishizuka O, Tani K, Harigane Y, Reagan MK, Stern RJ, Taylor RN, Sakamoto I (2012) Evidence for Mesozoic basement in the Izu-Bonin-Mariana arc system. In: Abstracts of the Japan Geoscience Union Meeting. Japan Geoscience Union, Makuhari, Chiba Japan, 20-25 May 2012

Ishizuka O, Taylor RN, Ohara Y, Yuasa M (2013) Upwelling rifting and ageprogressive magmatism from the Oki-Daito mantle plume. Geology 41(9):1011-1014. doi:10.1130/G34525.1

Ishizuka O, Tani K, Reagan MK (2014) Izu-Bonin-Mariana forearc crust as a modern ophiolite analogue. Elements 10:115-120. doi:10.2113/gselements.10.2.115

Ishizuka O, Tani K, Harigane Y, Yamazaki T, Ohara Y, Kusano Y, Exp. 351 Sci Party (2015) Geologic and geochronological constraints on the Philippine Sea tectonics around $50 \mathrm{Ma}$. In: Abstracts of the Japan Geoscience Union Meeting. Japan Geoscience Union, Makuhari, Chiba Japan, 24-28 May 2015

Johnson L, Fryer P, Taylor B, Silk M, Jones DL, Sliter W, Itaya T, Ishii T (1991) New evidence for crustal accretion in the outer Mariana fore arc: Cretaceous radiolarian cherts and mid-ocean ridge basalt-like lavas. Geology 19:811-814

Johnson JA, Hickey-Vargas R, Fryer P, Salters V, Reagan MK (2014) Geochemical and isotopic study of a plutonic suite and related early volcanic sequences in the southern Mariana forearc. Geochem Geophys Geosyst 15:589-604. doi:10.1002/2013GC005053

Jolivet L, Huchon P, Rangin C (1989) Tectonic setting of Western Pacific marginal basins. Tectonophysics 160:23-47

Kaiho K (1992) Eocene to Quaternary benthic foraminifers and paleobathymetry of the Izu-Bonin arc, Legs 125 and 126. In: Taylor B, Fujioka K et al. (eds) Proc. Ocean Drilling Program, Sci Results, Vol 126. College Station, Texas, Ocean Drilling Program, pp 285-310

Kamenetsky VS, Crawford AJ, Eggins S, Muhe R (1997) Phenocryst and melt inclusion chemistry of near-axis seamounts, Valu Fa Ridge, Lau Basin: insight into mantle wedge melting and the addition of subduction components. Earth Planet Sci Lett 151:205-223

Kao H, Chen W-P (1991) Earthquakes along the Ryukyu-Kyushu Arc: strain segmentation, lateral compression, and the thermo-mechanical state of the plate interface. J Geophys Res 96:21443-21485

Karig DE, Glassley WE (1970) Dacite and related sediment from the West Mariana Ridge, Philippine Sea. GSA Bull 81:2143-2146. doi:10.1130/0016-7606(1970)81

Karig DE (1971a) Origin and development of marginal basins in the western Pacific. J Geophys Res 76:2542-2561

Karig DE (1971b) Structural history of the Mariana island arc system. GSA Bull 82: 323-344. doi:10.1130/0016-7606(1971)82

Karig DE (1972) Remnant arcs. GSA Bull 83:1057-1068. doi:10.1130/00167606(1972)83

Karig DE (1975) Basin genesis in the Philippine Sea. In: Karig DE, Ingle JC Jr (eds) Initial Reports of the Deep Sea Drilling Project 31. U.S. Government Printing Office, Washington, pp 857-879. doi:10.2973/dsdp.proc.31.142.1975

Karig DE (1982) Initiation of subduction zones: implications for arc evolution and ophiolite development. In: Leggett JK (ed) Trench-Forearc Geology: Sedimentation and Tectonics on Modern and Ancient Active Plate Margins. Geol Soc London Spec Publ, London, pp 563-576

Kato T, Beavan J, Matsushima T, Kotake YJ, Camacho T, Nakao S (2003) Geodetic evidence of back-arc spreading in the Mariana Trough. Geophys Res Lett 30(12):1625. doi:10.1029/2002GL016757

Kuo B-Y, Chi W-C, Lin C-R, Chang ET-Y, Collins J, Liu C-S (2009) Two-station measurement of Rayleigh wave phase velocities for the Huatung basin, the westernmost Philippine Sea, with OBS: implications for regional tectonics. Geophys J Int 179:1859-1869. doi:10.1111/j.1365-246X.2009.04391.x

Kobayashi K (2004) Origin of the Palau and Yap trench-arc systems. Geophys J Int 157:1303-1315. doi:10.1111/j.1365-246X.2003.02244.x

Kreemer C, Blewitt G, Klein EC (2014) A geodetic plate motion and global strain rate model. Geochem Geophys Geosyst 15:3849-3889. doi:10.1002/2014GC005407

Lagabrielle Y, Karpoff AM, Cotton J (1992a) Mineralogical and geochemical analyses of sedimentary serpentinites from conical seamount (Hole 778A): Implications for the evolution of serpentine seamounts. Proc Ocean Drill Program Sci Results 125:325-342

Lagabrielle Y, Sizun J-P, Arculus RJ et al (1992b) The constructional and deformational history of the igneous basement penetrated at Site 786. In: Fryer P, Pearce JA, Stokking LB (eds) Proc. Ocean Drilling Program, Sci Results, Vol 125. Ocean Drilling Program, College Station, Texas, pp 263-276
Lagabrielle Y, Goslin J, Martin H, Thirot JL, Auzende JM (1997) Multiple active spreading centers in the hot North Fiji Basin (Southweast Pacific): a possible model for Archean seafloor dynamics? Earth Planet Sci Lett 149:1-13

Lallemand SE, Schnurle P, Manoussis S (1992) Reconstruction of subduction zone paleogeometries and quantification of upper plate material losses caused by tectonic erosion. J Geophys Res 97:217-240

Lallemand SE, Schnurle P, Malavieille J (1994) Coulomb theory applied to accretionary and non-accretionary wedges - Possible causes for tectonic erosion and/or frontal accretion. J Geophys Res 99:12033-12055

Lallemand SE (1995) High rates of arc consumption by subduction processes: some consequences. Geology 23:551-554

Lallemand SE (1996) Impact of tectonic erosion by subduction processes on intensity of arc volcanism. Island Arc 5(1):16-24

Lallemand SE et al (1998) Possible interaction between mantle dynamics and high rates of arc consumption by subduction processes in Circum-Pacific area. In: Flower MFJ (ed) Mantle Dynamics and Plate Interactions in East Asia. Geodyn Ser 27. AGU, Washington DC, pp 1-9

Lallemand S, Popoff M, Cadet J-P, Deffontaines B, Bader A-G, Pubellier M, Rangin C (1998) The junction between the central and the southern Philippine Trench. J Geophys Res 103(B1):933-950

Lallemand S, Liu CS, Dominguez S, Schnürle P, Malavieille J, ACT scientific crew (1999) Trench-parallel stretching and folding of forearc basins and lateral migration of the accretionary wedge in the southern Ryukyus: a case of strain partition caused by oblique convergence. Tectonics 18(2):231-247

Lallemand S, Font Y, Bijwaard H, Kao H (2001) New insights on 3-D plates interaction near Taiwan from tomography and tectonic implications. Tectonophysics 335(3-4):229-253

Lallemand S, Huchon P, Jolivet L, Prouteau G (2005) Convergence lithosphérique Vuibert (ed). Vuibert, Paris, France

Lallemand S (2014) Strain modes within the forearc, arc and back-arc domains in the Izu (Japan) and Taiwan arc-continent collisional settings. J Asian Earth Sci 86:1-11. doi:10.1016/j.jseaes.2013.07.043

Lebrun JF, Lamarche G, Collot JY (2003) Subduction initiation at a strike-slip plate boundary: The Cenozoic Pacific-Australian plate boundary, south of New Zealand. J Geophys Res 108(B9):2453. doi:10.1029/2002JB002041

Lee TY, Lawver LA (1995) Cenozoic plate reconstruction of Southeast Asia. Tectonophysics 251:85-138

Leng W, Gurnis M (2011) Dynamics of subduction initiation with different evolutionary pathways. Geochem Geophys Geosyst 12:Q12018. doi:10.1029/2011GC003877

Leng W, Gurnis M, Asimow P (2012) From basalts to boninites: the geodynamics of volcanic expression during induced subduction initiation. Lithosphere 4(6):511-523. doi:10.1130/L215.1

Leng W, Gurnis M (2015) Subduction initiation at relic arcs. Geophys Res Lett 42:7014-7021. doi:10.1002/2015GL064985

Lewis SD, Hayes DE, Mrozowski CL (1982) The origin of the west Philippine basin by inter-arc spreading. In: Balkce GR, Zanoria F (eds) Geology and tectonics of Luzon and Marianas region. Proceedings of CCOP-IOC-SEATAR Workshop, Manila, Philippines. Spec. Publ. 1, Philipp. SEATAR Comm, Manila, pp 31-51

Lewis SE, Hayes DE (1983) The tectonics of northward propagating subduction along Eastern Luzon, Philippine Islands. In: Hayes DE (ed) The tectonic and geologic evolution of SE Asian seas and islands: Part II, Geol Monogr 27. AGU, Washington DC, pp 57-78

Li C, van der Hilst RD (2010) Structure of the upper mantle and transition zone beneath southeast Asia from traveltime tomography. J Geophys Res 115. doi: 10.1029/2009JB006882

Macpherson CG, Hall R (2001) Tectonic setting of Eocene boninite magmatism in the Izu-Bonin-Mariana forearc. Earth Planet Sci Lett 186:215-230

Malavieille J, Lallemand SE, Dominguez S, Deschamps A, Lu C-Y, Liu C-S, Schnürle P, the ACT scientific crew (2002) Arc-continent collision in Taiwan: new marine observations and tectonic evolution. Geol Soc Am Spec Paper 358:187-211

Martinez F, Fryer P, Baker NA, Yamazaki T (1995) Evolution of backarc rifting: Mariana Trough, 20-24 N. J Geophys Res 100:3807-3827

Martinez F, Fryer P, Becker N (2000) Geophysical Characteristics of the Southern Mariana Trough, $11^{\circ} 50^{\prime} \mathrm{N}-13^{\circ} 40^{\prime} \mathrm{N}$. J Geophys Res 105:16,591-516,608

Matsuda J, Saito K, Zasu S (1975) K-Ar age and Sr isotope ratio of the rocks in the manganese nodules obtained from the Amami Plateau, Western Philippine Sea. In: Symposium on Geological Problems of the Philippine Sea. Geol Soc Japan, Japan, pp 91-98

McCabe R, Uyeda S (1983) Hypothetical model for bending of the Mariana Arc. In: Hayes DE (ed) The Tectonic and Geologic Evolution of Southeast Asian Seas and Islands Part 2. AGU, Washington, D.C., United States, pp 281-293 
McCaffrey R, Silver EA, Raitt RW (1980) Crustal structure of the molucca Sea collision zone, Indonesia. In: Hayes DE (ed) The tectonic and geologic evolution of Southeast Asian seas and islands, part 1, vol 23, Am Geophys Union, Geophys Monogr Ser., pp 161-178

McCaffrey R (1992) Oblique plate convergence, slip vectors, and forearc deformation. J Geophys Res 97(B6):8905-8915

Meckel TA, Coffin MF, Mosher S, Symonds P, Bernardel G, Mann P (2003) Underthrusting at the Hjort Trench, Australian-Pacific plate boundary: Incipient subduction? Geochem Geophys Geosyst 4(12):1099. doi:10.1029/2002GC000498

Mitchell JG, Peate DW, Murton BJ, Pearce JA, Arculus RJ, van der Laan SR (1992) K-Ar dating of samples from sites 782 and 786 (Leg 125): The Izu-Bonin forearc region. Proc Ocean Drill Program Sci Results 125:203-210

Mizuno A, Okuda Y, Nagumo S, Kagami H, Nasu N (1978) Subsidence of the Daito Ridge and associated basins, North Philippine Sea. In: Watkins JS et al. (eds) Geological and Geophysical Investigations of Continental Margins, AAPG Mem 29:239-243

Meckel TA, Mann P, Mosher S, Coffin MF (2005) Influence of cumulative convergence on lithospheric thrust fault development and topography along the Australian plate boundary south of New Zealand. Geochem Geophys Geosyst 6:9. doi:10.1029/2005GC000914

Meijer A, Reagan M, Ellis H, Shafiqullah M, Sutter J, Damon J, Kling S (1983) Chronology of volcanic events in the eastern Philippine Sea. In: Hayes DE (ed) The Tectonic and Geological Evolution of Southeast Asian Seas and Islands, Part 2, American Geophysical Union, vol 27. AGU Geophys Monogr, Washington, DC, pp 349-359

Metcalf RV, Shervais JW (2008) Supra-subduction zone (SSZ) ophiolites: is there really an "ophiolite conundrum"? In: Wright JE, Shervais JW (eds) Ophiolites, vol 438, Arcs, and Batholiths: A Tribute to Cliff Hopson: Geological Society of America Special Paper., pp 191-222. doi:10.1130/2008.2438(07)

Monzier M, Danyushevsky LV, Crawford NJ, Bellon H, Cotter J (1993) High-ME andesites from the southern termination of the New Hebrides island arc (SW Pacific). J Volc Geoth Res 57:193-217

Moore GF, Silver EA (1982) Collision processes in the northern Molucca Sea. In: Hayes DE (ed) The Tectonic and Geologic Evolution of Southeast Asian Seas and Islands: Part 2, Geophys Monogr AGU 27. AGU, Washington, D.C., United States, pp 360-372

Morishita T, Tani K, Shukuno H, Harigane Y, Tamura A, Kumagai H, Hellebrand E (2011) Diversity of melt conduits in the Izu-Bonin-Mariana forearc mantle: implications for the earliest stage of arc magmatism. Geology 39(4):411-414

Mrozowski CL, Lewis SD, Hayes DE (1982) Complexities in the tectonic evolution of the West Philippine Basin. Tectonophysics 82:1-24

Natland JH, Tarney J (1981) Petrologic evolution of the Mariana Arc and back-arc basin system - a synthesis of drilling results in the South Philippine Sea. Initial Rep Deep Sea Drill Proj 60:877-908

Nishizawa A, Kaneda K, Katagiri Y, Oikawa M (2014) Wide-angle refraction experiments in the Daito Ridges region at the northwestern end of the Philippine Sea plate. Earth Planets Space 66:25. doi:10.1186/1880-5981-66-25

O'Connor JM, Steinberger B, Regelous M, Koppers AA, Wijbrans JR, Haase KM, Stoffers P, Jokat W, Garbe-Schönberg D (2013) Constraints on past plate and mantle motion from new ages for the Hawaiian-Emperor Seamount Chain. Geochem Geophys Geosyst 14:4564-4584. doi:10.1002/ggge.20267

Ohara Y, Fujioka K, Ishizuka O, Ishii T (2002) Peridotites and volcanics from the Yap arc system and their tectonic implications. Chem Geol 189:35-53

Ohara Y, Kato Y, Yoshida T, Nishimura A (2015) Geoscientific characteristics of the seafloor of the Southern Ocean of Japan revealed by Japan's continental shelf survey. J Geogr 124:5. doi:10.5026/jgeography.124.0000

Okino K, Kato Y (1992) What is the Oki-Daito Ridge? Rept Hydrogr Res 28:269-292. In: Japanese with English abstract

Okino K, Shimakawa Y, Nagaoka S (1994) Evolution of the Shikoku basin. J Geomag Geoelectr 46:463-479

Okino K, Kasuga S, Ohara Y (1998) A new scenario of the Parece Vela basin genesis. Mar Geophys Res 20(1):21-40

Okino K, Ohara Y, Kasuga S, Kato Y (1999) The Philippine Sea: A new survey results reveal the structure and history of the marginal basins. Geophys Res Lett 26:2287-2290

Okino K, Fujioka K (2003) The central basin spreading center in the Philippine Sea: structure of an extinct spreading center and implications for marginal basin formation. J Geophys Res 108:2040. doi:10.1029/2001JB001095

Okino K, Ohara Y, Fujiwara T, Lee S-M, Koizumi Kl, Nakamura Y, Wu S (2009) Tectonics of the southern tip of the Parece-Vela Basin, Philippine Sea Plate. Tectonophysics 466:213-228. doi:10.1016/j.tecto.2007.11.017
Pacanovsky KM, Davis DM, Richardson RM, Coblentz DD (1999) Intraplate stresses and plate-driving forces in the Philippine Sea Plate. J Geophys Res 104:1095-1110

Park J-O, Hori T, Kaneda Y (2009) Seismotectonic implications of the KyushuPalau ridge subducting beneath the westernmost Nankai forearc. Earth Planets Space 61:1013-1018

Pearce JA, Thirlwall ME, Ingram G, Murton BJ, Arculus RJ, Van Der Laan SR et al (1992) Isotopic evidence for the origin of boninites and related rocks drilled in the Izu-Bonin (Ogasawara) forearc, Leg 125. In: Fryer P, Pearce JA, Stokking LB (eds) Proceedings of the Ocean Drilling Program, Sci Res, vol 125., pp 237-261

Pubellier M, Ali J, Monnier C (2003) Cenozoic plate interaction of the Australia and Philippine Sea Plates: "hit-and-run" tectonics. Tectonophysics 363:181-199. doi:10.1016/S0040-1951(02)00671-6

Pubellier M, Monnier C, Maury R, Tamayo R (2004) Plate kinematics, origin and tectonic emplacement of supra-subduction ophiolites in SE Asia. Tectonophysics 392:9-36. doi:10.1016/j.tecto.2004.04.028

Queano K, Ali JR, Milsom J, Aitchison J, Pubellier M (2007) North Luzon and the Philippine Sea Plate motion model: insights following paleomagnetic, structural, and age-dating investigations. J Geophys Res 112B, B05101. doi.org/10.1029/2006JB004506

Rangin C, Jolivet L, Pubellier M (1990) A simple model for the tectonic evolution of southeast Asia and Indonesian region for the past 43 My. Bull Geol Soc France 8(6):889-905, VI

Rangin C, Spakman W, Pubellier M, Bijwaard H (1999) Tomographic and geological constraints on subduction along the eastern Sundaland continental margin (South-East Asia). Bull Soc Geol France 170(6):775-788

Reagan MK, Hanan BB, Heizler MT, Hartman BS, Hickey-Vargas R (2008) Petrogenesis of volcanic rocks from Saipan and Rota, Mariana Islands, and implications for the evolution of nascent island arcs. J Petrol 49:441-464. doi:10.1093/petrology/egm087

Reagan MK, Ishizuka O, Stern RJ, Kelley KA, Ohara Y, Blichert-Toft J, Bloomer SH, Cash J, Fryer P, Hanan BB, Hickey-Vargas R, Ishii T, Kimura JI, Peate DW, Rowe MC, Woods M (2010) Fore-arc basalts and subduction initiation in the Izu-Bonin-Mariana system. Geochem Geophys Geosyst 11, Q03X12. doi.org/10.1029/2009GC002871

Reagan MK, McClelland WC, Girard G, Goff KR, Peate DW, Ohara Y, Stern RJ (2013) The geology of the southern Mariana fore-arc crust: Implications for the scale of Eocene volcanism in the western Pacific. Earth Planet Sci Lett 380:41-51. doi:10.1016/j.epsl.2013.08.013

Ribeiro J, Stern RJ, Martinez F, Ishizuka O, Merle SG, Kelley KA, Anthony EY, Ren M, Ohara Y, Reagan M, Girard G, Bloomer SH (2013) Geodynamic evolution of a forearc rift in the southernmost Mariana Arc. Isl Arc 22:453-476. doi:10.1111/iar.12039

Richter C, Ali JR (2015) Philippine Sea Plate motion history: Eocene-recent record from ODP Site 1201, central West Philippine Basin. Earth Planet Sci Lett 410:165-173. doi:10.1016/j.epsl.2014.11.032

Sasaki T, Yamazaki T, Ishizuka O (2014) A revised spreading model of the West Philippine Basin. Earth Planets Space 66:83

Sdrolias M, Roest WR, Müller RD (2004) An expression of Philippine Sea plate rotation: the Parece Vela and Shikoku Basins. Tectonophysics 394:69-86. doi:10.1016/j.tecto.2004.07.061

Sdrolias M, Müller RD (2006) Controls on back-arc basin formation. Geochem Geophys Geosyst 7:4. doi:10.1029/2005GC001090

Seno T, Maruyama S (1984) Paleogeographic reconstruction and origin of the Philippine Sea. Tectonophysics 102:53-84

Seton M, Müller R, Zahirovic S, Gaina C, Torsvik T, Shephard G, Talsma A, Gurnis M, Turner M, Maus S, Chandler M (2012) Global continental and ocean basin reconstructions since 200 Ma. Earth-Sci Rev 113:212-270

Seton M, Flament N, Whittaker J, Müller RD, Gurnis M, Bower DJ (2015) Ridge subduction sparked reorganization of the Pacific plate-mantle system 60-50 million years ago. Geophys Res Lett 42:1732-1740. doi:10.1002/2015GL063057

Sharp WD, Clague DA (2006) 50-Ma initiation of Hawaiian-Emperor Bend records major change in Pacific Plate motion. Science 313:1281-1284. doi:10.1126/ science.1128489

Shemenda Al (1992) Horizontal lithosphere compression and subduction: constraints provided by physical modeling. J Geophys Res 97(B7):11097-11116

Shervais JW, Choi SH (2011) Subduction initiation along transform faults: the proto-Franciscan subduction zone. Lithosphere 4(6):484-496

Shinjo R, Ishizuka O (2015) Rethinking spreading model of the northwestern West Philippine Basin (WPB): ${ }^{39} \mathrm{Ar} /{ }^{40} \mathrm{Ar}$ dating and geochemical constraints. In: Abstracts of the Japan Geoscience Union Meeting. Japan Geoscience Union, Makuhari, Chiba Japan, 24-28 May 2015 
Sibuet J-C, Hsu S-K, Le Pichon X, Le Formal J-P, Reed D, Moore G, Liu C-S (2002) East Asia plate tectonics since $15 \mathrm{Ma}$ : constraints from the Taiwan region. Tectonophysics 344:103-134

Spence W (1987) Slab pull and the seismotectonics of subduction lithosphere. Rev Geophys 25:55-69

Steinberger B, Sutherland R, O'Connell RJ (2004) Prediction of Emperor-Hawail seamount locations from a revised model of plate motion and mantle flow. Nature 430:167-173. doi:10.1038/nature02660

Stern RJ, Fouch MJ, Klemperer SL (2003) An overview of the Izu-Bonin-Mariana subduction factory. In: Eiler J (ed) Inside the Subduction Factory. Geophys Monogr 138, American Geophysical Union, Washington, D.C, pp 175-222

Stern RJ, Bloomer SH (1992) Subduction zone infancy: examples from the Eocene Izu-Bonin-Mariana and Jurassic California arcs. Geol Soc Amer Bull 104:1621-1636

Stern RJ, Reagan M, Ishizuka O, Ohara Y, Whattam S (2012) To understand subduction initiation, study forearc crust: to understand forearc crust, study ophiolites. Lithosphere. doi:10.1130/L183.1

Stern RJ, Tamura Y, Masuda H, Fryer P, Martinez F, Ishizuka O, Bloomer SH (2013) How the Mariana volcanic arc ends in the south. Island Arc 22:133-148

Stüben D, Neumann T, Taibi NE, Glasby GP (1998) Segmentation of the southern Mariana back-arc spreading center. Island Arc 7:513-524

Tani K (2010) RN Yokosuka YK10-04 Shinkai6500 \& Deep Tow surveys. JAMSTEC Cruise Report Apr 22, 2010 - May 10, 2010. JAMSTEC, Japan

Tani K, Myojinsho W (2011) RN Yokosuka YK11-07 Shinkai6500 \& Deep Tow surveys. JAMSTEC Cruise Report Sept 16, 2011 - Oct 2, 2011. JAMSTEC, Japan

Tani K, Ishizuka O, Ueda H, Shukuno H, Hirahara Y, Nichols ARL, Dunkley DJ, Horie K, Ishikawa A, Morishita T, Tatsumi Y (2012) Izu-Bonin Arc: Intra-oceanic from the beginning? Unraveling the crustal structure of the Mesozoic protoPhilippine Sea Plate. Abstract in AGU Fall Meeting 2012. AGU, Washington, D. C., United States

Tani K, Dunkley DJ, Chang Q, Nichols ARL, Shukuno H, Hirahara Y, Ishizuka O, Arima M, Tatsumi Y (2015) Pliocene granodioritic knoll with continental crust affinities discovered in the intra-oceanic Izu-Bonin-Mariana Arc: Syntectonic granitic crust formation during back-arc rifting. Earth Planet Sci Lett 424:84-94. doi:10.1016/j.epsl.2015.05.019

Taylor B, Brown G, Fryer P, Gill JB, Hochstaedter AG, Hotta H, Langmuir CH, Leinen M, Nishimura A, Urabe T (1990) Alvin-SeaBeam studies of the Sumisu Rift, Izu-Bonin arc. Earth Planet Sci Lett 100:127-147

Taylor B, Klaus A, Brown GR, Moore GF, Okamura Y, Murakami F (1991) Structural development of Sumisu Rift, Izu-Bonin Arc. J Geophys Res 96:16113-16129

Taylor B, Goodliffe AM (2004) The West Philippine Basin and the initiation of subduction revisited. Geophys Res Lett 31:L12602. doi:10.1029/2004GL020136

Taira A, Tokuyama H, Soh W (1989) Accretion tectonics and evolution of Japan. In: Ben-Avraham Z (ed) The Evolution of the Pacific Ocean Margins. Oxford Univ. Press, New York, pp 100-123

Tokuyama H (1985) Dredged igneous rocks from the Amami Plateau. In: Shiki T (ed) Geology of the Northern Philippine Sea. Tokai University Press, Tokyo, pp 50-56

Tokuyama H, Kagami H, Nasu N (1986) Marine geology and subcrustal structure of the Shikoku Basin and Daito Ridges Region in the northern Philippine Sea. Bull Ocean Res Inst Univ Tokyo 22:1-169

Tokuyama H (2007) Tectonic development and reconstruction of Philippine Sea Plate since late Cretaceous, Report on Deep Sea Survey Technology for Natural Resources in Japan. JOGMEC, Tokyo, pp 430-456

Toth J, Gurnis M (1998) Dynamics of subduction initiation at pre-existing fault zones. J Geophys Res 103:18,053-18,067. doi:10.1029/98JB01076

Uyeda S, Ben Avraham Z (1972) Origin and development of the Philippine Sea. Nature 40:176-178

Uyeda S, McCabe R (1983) A possible mechanism of episodic spreading of the Philippine Sea. In: Hashimoto M, Uyeda S (eds) Accretion Tectonics in the Circum-Pacific Regions: Proceedings of the Oji International Seminar on Accretion Tectonics, September 1981, Tomakomai, Japan, Reidel D. Mass, Norwell, pp 291-306

von Huene R, Lallemand S (1990) Tectonic erosion along the Japan and Peru convergent margin. Geol Soc Am Bull 102:704-720

von Huene R, Scholl DW (1991) Observations at convergent margins concerning sediment subduction, subduction erosion, and the growth of continental crust. Rev Geophys 29:279-316

von Huene R, Ranero CR, Watts P (2004) Tsunamogenic slope failure along the Middle America Trench in two tectonic settings. Mar Geol 203:303-317
Wang Z, Huang R, Huang J, He Z (2008) P-wave velocity and gradient images beneath the Okinawa Trough. Tectonophysics 455:1-13. doi:10.1016/j.tecto. 2008.03.004

Wei W, Xu J, Zhao D, Shi Y (2012) East Asia mantle tomography: new insight into plate subduction and intraplate volcanism. J Asian Earth Sci 60:88-103

Wei W, Zhao D, Xu J, Wei F, Liu G (2015) P and S wave tomography and anisotropy in Northwest Pacific and East Asia: constraints on stagnant slab and intraplate volcanism. J Geophys Res 120:1642-1666. doi:10.1002/ 2014JB011254

Weissel JK, Anderson R (1978) Is there a Caroline plate ? Earth Planet Sci Lett 41:143-158

Wessel P, Harada Y, Kroenke LW (2006) Toward a self-consistent, high-resolution absolute plate motion model for the Pacific. Geochem Geophys Geosyst 7:Q03L12

Whattam SA, Stern RJ (2011) The 'subduction initiation rule': a key for linking ophiolites, intra-oceanic forearcs, and subduction initiation. Contrib Mineral Petrol 162:1031-1045. doi:10.1007/s00410-011-0638-z

Whittaker J, Müller RD, Leitchenkov G, Stagg H, Sdrolias M, Gaina C, Goncharov A (2007) Major Australian-Antarctic plate reorganization at Hawaiian-Emperor bend time. Science 318:83-86. doi:10.1126/science.1143769

Widiyantoro S, Kennett BLN, van Der Hilst RD (1999) Seismic tomography with P and $\mathrm{S}$ data reveals lateral variations in the rigidity of deep slabs. Earth Planet Sci Lett 173:91-100

Yamamoto Y, Obana K, Takahashi T, Nakanishi A, Kodaira S, Kaneda Y (2013) Imaging the subducted Kyushu-Palau Ridge in the Hyuga-nada region, western Nankai Trough subduction zone. Tectonophysics 589:90-102. doi:10.1016/j.tecto.2012.12.028

Yamazaki T, Murakami F (1998) Asymmetric rifting of the northern Mariana Trough. Island Arc 7:460-470

Yamazaki T, Takahashi M, Iryu Y, Sato T, Oda M, Takayanagi H, Chiyonobu S, Nishimura A, Nakazawa T, Ooka T (2010) Philippine Sea Plate motion since the Eocene estimated from paleomagnetism of seafloor drill cores and gravity cores. Earth Planets Space 62(6):495-502

Yumul Jr GP (2007) Westward younging disposition of Philippine ophiolites and its implication for arc evolution. Island Arc 16:306-317. doi:10.1111/j.14401738.2007.00573.x

Zahirovic S, Seton M, Müller RD (2014) The Cretaceous and Cenozoic tectonic evolution of Southeast Asia. Solid Earth 5:227-273. doi:10.5194/se-5-227-2014

Zahirovic S, Müller DR, Seton M, Flament N (2015) Tectonic speed limits from plate kinematic reconstructions. Earth Planet Sci Lett 418:40-52. doi:10.1016/j.eps|2015.02.037

Zhao D, Yanada T, Hasegawa A, Umino N, Wei W (2012) Imaging the subducting slabs and mantle upwelling under the Japan Islands. Geophys J Int 190:816-828

\section{Submit your manuscript to a SpringerOpen ${ }^{\circ}$ journal and benefit from:}

- Convenient online submission

- Rigorous peer review

- Immediate publication on acceptance

- Open access: articles freely available online

- High visibility within the field

- Retaining the copyright to your article

Submit your next manuscript at $>$ springeropen.com 